\title{
Era-like GTP protein gene expression in rice
}

\author{
Expressão do gene da proteína GTP semelhante à era no arroz
}

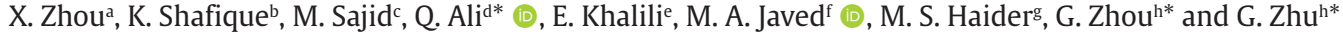 \\ aLinyi University, College of Life Science, Linyi, Shandong, China \\ ${ }^{\mathrm{b}}$ Government Sadiq College Women University, Department of Botany, Bahawalpur, Pakistan \\ 'University of Okara, Faculty of Life Sciences, Department of Biotechnology, Okara, Pakistan \\ dUniversity of Lahore, Institute of Molecular Biology and Biotechnology, Lahore, Pakistan \\ eTarbiat Modarres University, Faculty of Science, Department of Plant Science, Tehran, Iran \\ fUniversity of the Punjab Lahore, Department of Plant Breeding and Genetics, Lahore, Pakistan \\ sUniversity of the Punjab Lahore, Department of Plant Pathology, Lahore, Pakistan \\ hYangzhou University, The Ministry of Education of China, Joint International Research Laboratory of Agriculture and Agri-Product Safety, \\ Yangzhou, Jiangsu, China
}

\begin{abstract}
The mutations are genetic changes in the genome sequences and have a significant role in biotechnology, genetics, and molecular biology even to find out the genome sequences of a cell DNA along with the viral RNA sequencing. The mutations are the alterations in DNA that may be natural or spontaneous and induced due to biochemical reactions or radiations which damage cell DNA. There is another cause of mutations which is known as transposons or jumping genes which can change their position in the genome during meiosis or DNA replication. The transposable elements can induce by self in the genome due to cellular and molecular mechanisms including hypermutation which caused the localization of transposable elements to move within the genome. The use of induced mutations for studying the mutagenesis in crop plants is very common as well as a promising method for screening crop plants with new and enhanced traits for the improvement of yield and production. The utilization of insertional mutations through transposons or jumping genes usually generates stable mutant alleles which are mostly tagged for the presence or absence of jumping genes or transposable elements. The transposable elements may be used for the identification of mutated genes in crop plants and even for the stable insertion of transposable elements in mutated crop plants. The guanine nucleotide-binding (GTP) proteins have an important role in inducing tolerance in rice plants to combat abiotic stress conditions.
\end{abstract}

Keywords: GTP proteins, rice, mutations, transposons, alleles, gene sequencing.

\section{Resumo}

Mutações são alterações genéticas nas sequências do genoma e têm papel significativo na biotecnologia, genética e biologia molecular, até mesmo para descobrir as sequências do genoma de um DNA celular junto com o sequenciamento do RNA viral. As mutações são alterações no DNA que podem ser naturais ou espontâneas e induzidas devido a reações bioquímicas ou radiações que danificam o DNA celular. Há outra causa de mutações, conhecida como transposons ou genes saltadores, que podem mudar sua posição no genoma durante a meiose ou a replicação do DNA. Os elementos transponíveis podem induzir por si próprios no genoma devido a mecanismos celulares e moleculares, incluindo hipermutação que causou a localização dos elementos transponíveis para se moverem dentro do genoma. $\mathrm{O}$ uso de mutações induzidas para estudar a mutagênese em plantas cultivadas é muito comum, bem como um método promissor para a triagem de plantas cultivadas com características novas e aprimoradas para a melhoria da produtividade e da produção. A utilização de mutações de inserção por meio de transposons ou genes saltadores geralmente gera alelos mutantes estáveis que são marcados quanto à presença ou ausência de genes saltadores ou elementos transponíveis. Os elementos transponíveis podem ser usados para a identificação de genes mutados em plantas de cultivo e até mesmo para a inserção estável de elementos transponíveis em plantas de cultivo mutadas. As proteínas de ligação ao nucleotídeo guanina (GTP) têm papel importante na indução de tolerância em plantas de arroz para combater as condições de estresse abiótico.

Palavras-chave: proteínas GTP, arroz, mutações, transposons, alelos, sequenciamento de genes.

*e-mail: gszhou@yzu.edu.cn; zhuguang2007@163.com; saim1692@gmail.com

Received: April 5, 2021 - Accepted: June 19, 2021 


\section{Introduction}

Rice grains are the most essential among the cereal crops that is consumed by over half of the humans (Schwarz-Sommer et al., 1985). Globally, it is an important source of energy in diet of almost 3 billion people that becomes 35-75\% calories intake per day (Takano et al., 2001). The cultivation of rice has covered the area of 153 million hectares which is almost $11 \%$ of the whole world cultivated lands and the average annual yield is 480 million metric tons (Pocketbook 2015). It is mainly cultivated in tropical and subtropical areas of the world. There are more than 114 rice growing countries in the world. About 90\% of the world's rice is grown and consumed in Asia (May and Martienssen 2003). China, India, Pakistan, Bangladesh, Thailand, Vietnams and Philippines are the major rice growing and consuming countries of the world (Miyao et al., 2007). The importance of rice can be seen throughout the world from fact that The United Nations acknowledged 2004 "the year of rice" (Speulman et al., 2000).

Rice is a rich source of nutrients that are essential in our diet. It contains modest protein contents but in nutritional quality it ranks high among cereals. It provides around $21 \%$ for human per capita energy as well as $15 \%$ of per capita protein, worldwide (Lin et al., 2006). It contains 77\% carbohydrates (Feschotte et al., 2002). The protein quality of rice is superior to wheat but per hectare production of wheat protein is higher than that of rice (Wang et al., 2005). Rice is a cheap source for fibers, vitamins and minerals like thiamin, riboflavin, niacin, zinc, phosphorus, copper and magnesium. As compared to other cereals, rice has special gluten protein composed of a stable amino acid sequence (Agrawal et al., 2001). The grain of rice is also called as caryopsis which is one-seeded natural dry product, which has pericarp incorporated with seed coat of grain. The essential part of the rice grain is husk, pericarp, endosperm and fetus (Luck et al., 1998). Short-grain rice contains more starch and cooks softer than long-grain rice. In many countries, rice straw and bran are used as animal feed. Resistant starch is also present in rice, keeping the bowel healthy because it remains undigested and helpful in the growth of beneficial bacteria (Kuromori et al., 2009).

In Pakistan, rice is a significant cash crop, as it covers $52 \%$ area of the total cultivated area of rice in Pakistan. It accounts for almost two million tons to our food requirements and is a significant source of revenue generation of rural households (Chin et al., 1999). Among most of the important rice varieties of rice, mainly "Basmati" is most popular for its grain length and aromatic properties throughout the whole world (Chuck et al.,, 1993). Rice is mostly cultivated in two provinces in Pakistan i.e. Punjab and Sindh. These two regions account over $88 \%$ of all rice production (Dias et al., 2008). Gujranwala, Sialkot, Narowal, Sheikhupura, Lahore, Khairpur, Nawabshah, Sukkhur and Hyderabad are well-known regions of rice cultivation in Pakistan. Production and cultivated area of rice has increased to seven thousand tons and 2,899 thousand hectares during 2017-18 than the previous years. Pakistan earns $13 \%$ of country's foreign exchange from rice export. $0.6 \%$ of Pakistan's GDP is covered by production of Rice and
$3.1 \%$ of the value-added in agriculture which improve the economy of Pakistan (Chandlee, 1990; Enoki et al., 1999). About 47\% population of Pakistan is considered as food insecure (Khush, 1997; Kikuchi et al., 2003).

Rice is a monocot semi-aquatic annual grass plant belongs to genus Oryza and family Poaceae (Bhatt and Dean, 1992; Camacho et al., 2003). There are 22 wild taxa in Oryza genus in which two species are very important for human consumption i.e. Oryza sativa L. also known as the Asian rice as well as the Oryza glaberrima Steud which is also known as African rice. There are further divisions in Oryza species i.e. Oryza officinalis, Oryza ridelyi and Oryza rufipogon (Jiang et al.,, 2003; Jiang et al., 2004). From 22 wild species of Oryza, fifteen were originated in Asia while seven in Sub-Saharan Africa (Turcotte et al., 2001; Wang et al., 2005). Wild species of Oryza carries specific characters like biotic and abiotic stress resistance, and these genes are very useful in interspecific rice breeding programs (Ahmad et al., 2021; Ali and Malik 2021; Yousef et al., 2020). Oryza sativa was firstly produced in Southeast Asia and now mainly produced in all rice growing regions of the world except Antarctica like in Europe, Africa, Middle East and America. On the other hand, O. glaberrima has no subspecies and is only cultivated in Africa (Balqees et al., 2020; Bashir et al., 2020; Dufresne et al., 2008). It has various useful genetic characters such as grain shattering resistance, lodging and drought tolerance, blast and nematode resistance. But it has lower grain yield potential; hence, it is rapidly replaced by O. Sativa (Bishop et al., 1996; Chin et al., 1999; Chopra et al., 1999).

The cultivated Oryza varieties have been categorized into three ecotypes; Javanica, Japonica and Indica. Indica was adapted in tropics and sub-tropics regions of Asia. Javanica cultivated in Indonesia, Philippines and Madagascar hilly regions while the temperate regions of Korea, Northern China and Japan are covered by Japonica. Both Japonica and Indica varieties are cultivated in Pakistan (Chin et al., 1999; Emmanuel and Levy, 2002).

Probably, the world population has been expected to increase 10 billion people and the population of Pakistan is expected to increase 208 million to 270 million people by 2050 , which will increase the need of rice demands (Balqees et al., 2020; Bashir et al., 2020; Kim et al., 1987). However, the world rice production is increasing but this increase is not relative to the demand of growing human population. About $70 \%$ production increase has to be gained to fulfill the need of increasing population in the next 30 years (Komatsu et al., 2003; Koonin and Galperin 2002). The first choice or way is to increase the area under rice cultivation, which is seem to get difficult as the agricultural land is being changed in to living colonies and societies in most of the progressive countries. So, high yielding, abiotic and biotic resistance rice varieties should have to be developed to increase the yield of rice by adopting molecular breeding approaches. Thus, the increasing of yield in rice may take part in hunger annihilation, food security, poverty reduction as well as the financial improvement throughout the entire world (Masood et al., 2020; Nawaz et al., 2020; Shafique et al., 2020a, b). 
Oryza sativa is a diploid $(2 \mathrm{n}+2 \mathrm{x}=24)$ monocotyledon cereal plant while some wild species of Oryza are tetraploid $(2 n=48)$. The basic chromosome number of all species of Oryza is $\mathrm{n}=12$. The genome of rice is completely sequenced after dicotyledon Arabidopsis thaliana and hence become the second plant species whose genome has been sequenced (Kolesnik et al., 2004; Komatsu et al., 2003; Naito et al., 2009). Rice is the model cereal plant due to its smaller genome size $389 \mathrm{Mb}$ and 32,000 to 50,000 are predicted genes (Goff et al., 2002). There are some important factors that attract scientists to utilize rice as an excellent plant genomic system, both in sense of studying the gene expression, functional genomics and sequencing which make rice a model plant species such important factors are: the construction of high-density physical and genetic maps, the establishment for highly efficient and cheap genetic manipulation system as well as high-syntenic relationships with other cereal crop genomes (Greco et al., 2001; Haseeb et al., 2020). Sequencing of the rice genome opened a gateway in plant biology research that increases the importance of plant biotechnology. Rice germplasm is a rich reservoir of valuable genes (Fitzmaurice et al., 1992; Fujino et al., 2005; Ghafoor et al., 2020). A unique opportunity has been developed to identify and functionally characterize the genes that were involved in biochemical pathways responsible for abiotic and biotic stress resistance, consumer quality and agronomic performance. Oryza germplasm is a vital source of interspecific rice breeding, hence, significantly contributes to world food security (Harris, 2002; Hirochika, 1997; Hirochika et al., 2001).

To improve the crop production, there is need to study the basic genome statistics; therefore rice is developed as an exemplary system to explain the importance of information evolving from basic genome. An important aspect of studying genome science is to understand the basic information about genes and pathways that is learned by studying that one specie can eagerly be transmitted to another specie. Now-a-days, geneticists are mostly trained to conclude the information about what an individual gene of a model species do that are perceived in controlled environment; this helps to understand and study the behavior of homologous genes in complex crop genome of interrelated field environment. As a consequence, the study of rice genomics assures to understand the major insights into the genetic functional and structural importance of genes in many other crop species (Hsing et al., 2007; Huang et al., 2009; Iqbal et al., 2021; Iqra et al., 2020).

Complete genome sequence of both japonica and indica subspecies of rice have been released but the experimental studies of many functional genes in rice genome have not completed yet (Izawa et al., 1997; James Junior et al., 1995). One of the most challenging goals is now to examining the functioning of large number of genes. Description of some particular genes has revealed that many intermediate elements in developmental pathways, predominantly proteins which act in signal transduction pathways remain highly conserved. The $\mathrm{G}$ protein is incredible example of this that are also called molecular switches. These proteins function by means of conformational changes that occur due to the binding and hydrolysis of GTP through intrinsic activities (Ipek and Simon, 2002; Kaeppler et al., 2000).
One of the most significant proteins for all organisms is GTP-binding proteins which are different in eukaryotes and prokaryotes (Ishikawa et al., 2005; Jiang et al., 2003; Mathieu et al., 2009). These proteins are also termed as GTPases or G-proteins. It is found throughout all the domains of life which acts as a molecular switch that is "activated" by GTP molecule and "inactivated" by the hydrolysis of GTP molecule to GDP. It controls various cellular processes, for example reorganization of the cellular cytoskeleton, signal transduction, translation and regulation of transcription, vesicle trafficking and protein transport in the cell (Kumar and Hirochika 2001; Luck et al., 1998). All G-proteins have well-conserved motifs, G1, G2, G3, G4 and G5. These elements are very essential for the conversion of GDP/GTP, for GTP hydrolysis and GTP conformational change. G2 pattern is highly maintained in G-protein family and does not play any role in GDP/GTP exchange activity (Luo et al., 1991; Martienssen, 1998).

The superfamily of GTPases has been divided into four subfamilies: the heterotrimeric GTPases, small GTP binding proteins (Ras-like GTP-binding proteins), unique bacterial GTPases as well as translation factors (Aarts et al., 1993; Akram et al., 2021; Bazopoulou and Tavernarakis, 2009; Bhatt and Dean 1992). The binding of GTP induces changes in the proteins that permits communication with effector molecule, while the GDP bound state is inactive. In small GTPases, the conversion of GTP to GDP-bound state and GDP to GTP is usually regulated through two proteins: GDS (guanosine nucleotide dissociation stimulator) and GAP (GTPase activator). The GDS speed ups the replacement of GDP to GTPase as well as GTP activator increases GTP hydrolysis (Chandlee 1990; Chin et al.,1999). The heterotrimeric GTP binding proteins consist of three subunits, $\alpha, \beta$ and $\gamma$. These proteins together interface between elicitor systems and seven transmembrane segment receptors. Individually these heterotrimeric G-protein subunits interact with one seven transmembrane segment receptor and one elicitor system. The subunit (35-55 kDa) has GTPase binding site and the capability to hydrolyze GTP. The $\beta(40 \mathrm{kDa})$ and the $\gamma$ subunits are mostly isolated as a stable compound (Ali et al., 2020; Craciun et al., 2000; Fitzmaurice et al., 1992).

The small GTPase superclass may be divided into two large classes on the basis of their structure and arrangement: 1) SIMIBI class (the signal recognition particle) and 2) TRAFAC class (the translation factors). The SIMIBI class is involved in membrane transport activity, localization of proteins, a set of metabolic enzymes with phosphate transferase activity or kinase activity and in splitting of chromosomes (Fujino et al., 2005; Goff, 1999; Kaneko et al., 2004). On the contrary, the TRAFAC (translation factors) class that belongs to the P-loop GTPases, is a unique group of G-proteins. It is primarily identified by analyzing completely sequenced bacterial genomes and it includes proteins that are involved in cell motility and translation. The TRAFAC (translation factor) class is sub-divided into seven families: Era, OBG, YihA, TrmE, Hflx, YfgK and classic translation factor family (Turcotte et al., 2001; Walbot, 1992).

A Ras-like protein known as Era, was primarily found in E. coli and so termed as E. coli Ras-like protein (Era). Era 
has two conserved domains: the K Homology (KH) domain, which binds to the $E$. coli 30 S ribosomal subunits and the 16S rRNA and the GTPase domain, which is homologous to RAS and belonging to the TRAFAC class (Izawa et al., 1997; Takano et al., 2001; Yu et al., 2002). These proteins have low GTP hydrolysis activity and consisted of 316 amino acids. Era is necessary for cell division (Jeon and An 2001; Jiang and Ramachandran, 2010), cell growth and viability (Kaneko et al., 2004; Khush, 1997), and pleiotropic processes involving adaptation to thermal stress, carbon metabolism and fatty acid metabolism (Balqees et al., 2020; Bashir et al., 2020; Kempin et al., 1997). It is highly conserved in prokaryotes and eukaryotes. Era-like GTPase is found in dividing or metabolically active cells. It was firstly found in Antirrhinum majus plant. Research on DNA proposes that homologous arrangements with Era exist in several organisms including Antirrhinum majus, Caenorhabditis elegans, Drosophila, mouse, and human. In humans, EraL1 is the Era-like homolog (Farooq et al., 2021; Feschotte et al., 2002; Grandbastien, 1998).

By Immune-electron microscopy and subcellular fractionation the structure of Era is known; providing the evidence that Era is a peripheral membrane protein that is confined at the cytoplasmic surface of the inner membrane. However, it is not known yet that if Era interacts directly with the membrane or whether it plays a role as a GTPase involved in membrane signaling in a consistent manner. The physical function of eukaryotic Era-like GTPase is not known yet (Ueki and Nishii, 2008; Villalba et al., 2001).

\section{Rice as a model cereal genome}

Rice contain vulnerable features such as its small genome size (Tyagi and Mohanty, 2000), high efficient transformation technology (Speulman et al., 2000), commonly found resources of germplasm (Tyagi and Mohanty, 2000) and precise genome sequence due to its co-linearity with the sequences of other cereal crops (Yuan-Yuan and Zhang, 2006). These features have made Rice a model plant to study the functional genomics in monocotyledons (Tomita and Tanisaka, 2010; Wessler, 1989). The genome of rice is 3.5 times the size of the Arabidopsis genome (Terada et al., 2002; Wu et al., 2005). Rice, like other cereals, also has a GC-rich genome. All cultivated species of Oryza sativa have a diploid AA genome while the wild species are either allotetraploids or diploid with CC, BB, EE, CCDD or BBCC genomes (Steiner-Lange et al., 2001; van Enckevort et al., 2005). It is rich with germplasm resources, which is including artificially modified and naturally occurring germplasms (Hsing et al., 2007; Takano et al., 2001).

Many confusions were made in scientist community like genome of rice have competing annotations (James Junior et al., 1995; Jiang et al., 2003), which were resolved latter on through a single united annotation (Jiang et al., 2004; Kaneko et al., 2004). The complete sequencing of rice genome and numerous series of elucidation have delivered a basic understanding of genetic and molecular studies (Goff et al., 2002; Huang et al., 2009). Wide-ranging studies of rice genome and transcriptomics have been conducted to fulfill the increasing demand of food supplies (Hirochika et al., 2001; Komatsu et al., 2003; Koncz et al., 1989).

Future aims and approaches for rice have been designed and planned through the experience got from other model organisms, to illustrate the structure and biological function of genome in tissues and organs (Jeon and An, 2001; Kumar and Hirochika, 2001). Classification of the genes and their regulatory pathways are referred by the understanding of functional genomics for an agronomical important trait. After the classification of involved components, the whole process of gene regulation for related trait can be identified and assimilated to understand the functions of genome of complex trait which is very valuable in the practical implementation of rice genomic breeding (Larkin and Scowcroft, 1981; Walbot 2000).

Several researches provided evidence for syntenic relationship between rice and other cereals, which led to the suggestion that cereal genomes could be studied as a single genome (Takano et al., 2001; Wessler, 1989). However, the difference is present among cereal genomes at the level of genes collinearity (Saika et al., 2005; Tsugane et al., 2006). Still, the rice genome serves as a model system for determining how genes interact in controlling complex traits in plants (Proels and Roitsch, 2006; Sato et al., 1999). Complete genome sequence analysis of rice leads towards the gene prediction and analysis, although the function of genes can be identified which further requires precise tools for annotation. Different gene-prediction tools are available, no single program is completely accurate (Ross-Macdonald et al., 1999; Speulman et al., 2000; Tahir et al., 2020). The accuracy and preciseness of rice genome annotation have increased and furthermore, Full length rice cDNA is also available for more studies (Luck et al., 1998; Mathieu et al., 2009; McClintock, 1951). The advancement in high throughput genomic technologies has provided enormous quantity of sequence information about rice plant in different DNA databases e.g. EMBL, DDBJ and Genbank (Muqadas et al., 2020; Murai et al., 1991; Nakagawa et al., 2000). It has been reported that during eighties in Japan, the mapping population of the Rice Genome Programme was developed, which is the result of a combination of Japanese variety Nipponbare with an indica variety Kasalath (Chopra et al., 1999; Dias et al., 2008).

\section{Functional genomics studies of rice and its scope}

Improvement of rice is the main aim of the scientific community. Many core papers have revealed that the more research of rice genome can improve the yield of rice. Due to latest studies, the number of molecular markers was greatly increased and the physical sequence was understood and immediacy to annotated genes was in predicting the association of gene characteristics. In part, this is due to the decrease in the cost of DNA sequencing, which allows scientists to re-sequence the cell nucleotide types associated to rice reference genome and additional rice accessions (Mazier et al., 2007; McCarty et al., 1989). It has been proposed the key role of sequence-based analysis, 
these analyses are performed to study the variations in both wild and cultivated rice in order to investigate and analyze genetic variation. In order to fulfill the growing demand of food all over the world, Rice scientists produced a special variety known as “Green Super Rice” by understanding the molecular and genetic basis for important traits such as Phosphorus and Nitrogen (Miyao et al., 2007; Naito et al., 2009; Nakagawa et al., 2000). In Rice, the total number of loci is 56,797 in which 40,577 loci are non-TE loci that encode 50,939 gene models while on the other hand 16,220 loci are TE loci that encode for 16,454 genes models (Jiang and Ramachandran, 2010). The reference genome is also used to search the variations that are present in genome of whole Oryza genus (Javied et al., 2021; Larkin and Scowcroft, 1981; Lin et al., 2006; Luck et al., 1998) and furthermore, to explore their variants having closed homology to rice variety commonly cultivated worldwide (AA genome species) (Luo et al., 1991; Martienssen, 1998; Schwartz et al., 1998). International Oryza Map Alignment Project had provided many sources for the above explorations (Sazuka et al., 2005; Schneider et al., 2005; Suzuki et al., 2001).

The general objective of research on the functional genomics of rice is to understand how the genome functions to produce phenotype, by translating the information preserved in the sequences, including genes and regulatory elements at the whole genome level. The use of discoveries for the genetic improvement of rice is equally important that can be a model for other crops.

\section{Genes controlling traits and their characteristics in rice}

Wide relative mapping has interpreted that gene order is basically conserved among rice and other cultivated cereals chromosomes, thus allowing one to firstly isolate an important gene in rice and then to use it as a probe to isolate the homologues genes in other cereals ( $\mathrm{Qu}$ et al., 2009; Schmidt et al., 1987). Information about rice sequence can be used to enrich large genomic cereals with additional molecular markers which facilitate cloning of genes for important characters. Interpreting the rice genome sequence is a simple task because the sequencing procedures are now well established, effective and precise. However, the sequence is not the end and the most important task is to allocate a function to each gene, to identify the exon/intron structure and to annotate the sequence of each gene (Terryn et al., 1993). Several large blocks of tandem sequence repeats have been elaborated as well as assigned later on to the subtelomeric regions (Emmanuel and Levy, 2002). Several types of retrotransposable elements have been reported in rice (Saika et al., 2005). It has been reported Copia and Gypsy types and described the nested structures of both retrotransposons (Yamaguchi et al., 2006; Youssefian et al., 1993a). Numerous variants of transposable elements were discovered such as MITES (miniature inverted transposable elements), CACTA-like, En/Spm and Mariner-like. In an experiment, 73,000 BAC ends (Komatsu et al., 2003; Ma, 1994) and he found that 6,848 out of 73,000 similar to transposable elements in which retroelements were $88 \%$. Identification of important genes and finding of the function to every gene was a massive initiative. One of the main task is to increase the yield of Rice by working on its genome sequence.

Cloning of the Xa-21 resistance gene were accomplished by the libraries of BAC (Bacterial artificial chromosome) (Ashikari et al., 1999; Youssefian et al., 1993a). Through using the process of gene saturation in which target regions of gene of interest identified with different markers like EST, AFLP and RAPD etc. A very significant gene Xanthomonas campestris pv. Oryzae resistant gene also known as Xa21 was first cloned, (Ashikari et al., 1999; Sano et al., 1994). $\mathrm{Pi}-\mathrm{b}$ and $\mathrm{Pi}$-ta2 genes have been cloned and characterized which is responsible for the resistance to specific races of the rice blast agent, the fungus Magnaporthe grisea. Peng and his colleagues identified important traits such as semi dwarfism, heading date caused by Hd1 gene as a major QTL and isolated by positional cloning (Peng et al., 2017).

Chao and Avruch described that the functional characterization of important genes is possible through a process in which homologues of known genes were isolated and over-expressed ectopically (Chao and Avruch 2019). Furthermore, it promotes the characterization of several vital genes: OsRac1 and another gene that encodes a CDPK which is responsible for the tolerance against salt and cold (Charng et al., 2004), heme oxygenase (HO) gene responsible for the regulation of photoperiodic (Agrawal et al., 2001), MADS box genes that have important role in the development (Terryn et al., 1993), gene responsible for the control of cell death (Newman et al., 2015). More than 300 imprinted candidates were first recognized (Yuan-Yuan and Zhang 2006) in rice. Recently, the characterization and cloning of several genes are performing due to the presence of similarity to other species such as Arabidopsis known genes. Although, they contain very limited functional characterization.

Rice transformation, an essential tool for reverse genetics, has also made tremendous progress during the last 10 years. The first transgenic rice was obtained in 1988 through plasmid uptake of protoplasts. Agrobacterium tumefaciens and gene gun were successfully used to transform different types of rice in 1991 (Akram et al., 2021; Javied et al., 2021; Yamaguchi et al., 2006). Transformation not only works as a laboratory tool, nevertheless in many countries trails are being conducted to provide various improvements for nutritional value or disease resistance. With the rapid advancement of functional genomics technologies, important genes have been cloned which control main agronomic traits and their biological functions have also been characterized (Schneider et al., 2005; Takano et al., 2001).

The oldest method for gene isolation is map-based cloning. It has been widely used in the isolation of rice gene, generally for detecting natural mutations of traits that are agriculturally useful (Sato et al., 1999; Takagi et al., 2007). Single Nucleotide Polymorphisms (SNP)-based ultrahigh-density linkage maps are being constructed through new sequencing technology (Yuen et al., 2015), due to which the firmness and accuracy of mapping for quantitative trait loci has significantly been improved (van 
Houwelingen et al., 1999; Wessler, 1989). Insertional mutant libraries use both forward and reverse genetic methods and have become a main source of gene cloning (Huang et al., 2009). Forward genetic approach causes the screening of insertion lines by phenotype, co-segregation between the phenotype and the insertion of T-DNA is examined. The phenotypic effect of the gene is further confirmed by performing a complementation test (Hirochika et al., 1996; Kuromori et al., 2009). While in reverse genetic approach, the FSTs of the mutant databases are examined of the selected gene and the mutant attained is then analyzed for a phenotype. The main need of cloning genes is the functional characterization of genes that show variance expressions mostly from microarray analyses, e.g; treatment with abiotic stresses. The differentially expressed genes are subjected to knocking-out, over-expression and knocking-down. The phenotypic effects of these differentially expressed genes have also been analyzed (Koch et al., 2017; Kumar et al., 2020).

\section{Genetic control for yield improvement}

Grain yield is a complex trait determined by three major components: grain weight, number of grains per panicle and number of panicles per plant (Wang et al., 2015). The yield component traits of rice yield and their primary biological functions, and prepared a list of genes which have potential ability for yield improvement and highlighted some new advancement in identification of yield genes (Jiang and Ramachandran 2010). The number of tillers has increased significantly due to the over-expression of mRNA156, but the panicle size in rice has decreased (Kaeppler et al., 2000; Yu et al., 2002). OsSPL14, a target of miRNA156, is responsible for the architecture of the plant by controlling QTL IPA1 (Chen et al., 2015) OsSPL14 gene is highly expressed in the primordia of primary and secondary branches and in the shoot apex, which reduces the tiller number and supports panicle branching (Li et al., 2015). The pleiotropic effects on heading date, grain yield and plant height are conferred due to a QTL i.e.; DTH8 (Yuan-Yuan and Zhang, 2006; Yuen et al., 2015). The expression of MOC1 gene is also increased by DTH8 which is also tangled in the growth of panicle branching (Shan et al., 2015; Shi et al., 2017). The pleiotropic effect of Ghd7 and Ghd8 which encodes HAP2 and HAP3 subunits respectively and also showed that HAP proteins act as DNA binding proteins usually by building HAP2/HAP3/HAP5 trimeric complex.

\section{Genetic resistances for biotic stresses}

Rice as a crop can be severely damaged by many diseases and pests. Rice yields are significantly improved by the cloning of disease resistant genes. About 40 genes for bacterial blight resistance while 48 genes for blast resistance have been cloned and their functions have been characterized (Yuan-Yuan and Zhang, 2006). The first isolated gene was Xa21 gene encoding a receptor-like kinase. This gene endowed resistance to a wide range of different bacterial blight pathogen (Ahmad et al., 2021; Ali et al., 2020; van Houwelingen et al., 1999; Yousef et al., 2020). A gene known as Xa13 gene provides resistance to a specific bacterial blight pathogen strain known as PXO99 strain (Chandlee 1990; Chen et al., 2015). While the expression of wild-type Xa13 is necessary for inhibiting bacterial growth and enhancing the pollen development (Pinson et al., 2015). The first blast resistance gene isolated from rice was Pib. Pib belongs to R gene family. This gene translates the protein containing NBS-LRR structure (He et al., 1999; Xu et al., 2006). Almost all blast resistant genes consist of this structure. It has been characterized an important brown plant hopper resistance gene Bph14 which encodes a coiled-coiled, nucleotide-binding and leucine-rich repeat protein. Bph14 gene product activates the signaling pathway of salicylic acid which is similar to defense response regulated by disease resistance genes (Du et al., 2009, 2013).

\section{Genetic resistances abiotic stress}

Some of the major abiotic stresses that limit rice production are salinity, heat, drought \& cold etc. (Balqees et al., 2020; Haseeb et al., 2020; Tyagi and Mohanty 2000). To improve resistance for abiotic stress many genes have been identified by recent advancements. Above 100 rice genes have been identified that have shown several degrees of resistance to abiotic stress including five QLTs (Villalba et al., 2001; Wang et al., 2015). The over expression of some genes have been observed which shown resistance to various abiotic stresses. For Example, OsCIPK03, OsCIPK15 and OsCIPK12 over expression notably enhanced tolerance to drought, salt and cold stresses respectively (Xu et al., 2006). Similarly, over expression of OsCDPK7 improved resistance to drought and salt while over expression of OsCDPK13 significantly developed tolerance to cold (Dufresne et al., 2008; Farooq et al., 2021). OsSIK1 gene which is a presumed receptor-like kinase acts as a positive regulator in tolerance to salt stress and drought stress (Ahmad et al., 2021; Ali et al., 2020). DSM1 is a drought sensitive mutant induced by salt, abscisic acid (ABA), and drought encodes a putative MAPK kinase. The analysis of over expression of T-DNA insertion mutant dsm1 and DSM1 described that DSM1 has a positive effect on stress resistance (Fujino et al., 2005). Numerous transcriptional factors have also been identified as stress resistant (He et al., 1999; Huang et al., 2009). Calcium is also involved in stress signaling (Ahmad et al., 2021; Ghafoor et al., 2020).

Microarray analysis of cDNA showed that after drought stress SNAC1 gene expression was significantly produced in IRAT109 rice cultivar (Goff, 1999). It also showed that SNAC1 gene over expression increased drought tolerance without affecting agronomic performance at the reproductive stage of rice. Constitutive over expression of SNAC2 and OsNAC6 reduced plant growth, but increased resistance to cold, salt and drought stress in rice (Takasaki et al., 2010). Under drought stress, over expression of root specific OsNAC10 enhanced grain yield and improved drought tolerance in rice (Krasensky and Jonak, 2012). The over expression of 
OsbZIP23 greatly increased resistance to salt and drought stress and also increased sensitivity to ABA (Xiang et al., 2008). Members of zinc finger, MYB and AP2 families have also played regulatory roles in stress responses in rice (Xing et al., 2021).

In stress response, phyto-hormones like ethylene, auxin and ABA play significant roles. Zeaxanthin, is a precursor of $A B A$ encoded by dsm 2 gene, a putative $\beta$-carotene hydroxylase. The over expression of DSM2 has resulted in a significant increase in tolerance to drought and oxidative stress. ABA levels were significantly decreased in the dsm2 mutant after drought stress compared with wild type (Du et al., 2009). SNORKEL1, SNORKEL2 and Sub1A genes encode conferring resistance in rice (Hattori et al., 2009). A set of AP2/ERF family transcriptional factors was linked with the Sub1A-1-mediated submergence response (Mizoi et al., 2012). TLD1 encodes Indole-3-acetic acid (IAA)-amino synthetase that binds amino acids with IAA. Drought resistance is also improved by Gain-of-function mutant tld1-D (Zhang et al., 2009). Ren and his colleagues showed that SKC1 a QTL regulating salt tolerance gene, encode a high affinity HKT-type K+ transporters. An unknown protein encoded by qLTG3-1 controls germ inability in low-temperature (Ren et al., 2005). During seed germination, QLTG3-1 is expressed in the embryo and can help weaken embryonic tissue to aid germination (Fujino et al., 2008). A protein known as F-box protein is encoded by a cold tolerant QTL Ctb1. This F-box protein signifies association of the ubiquitin-proteasome pathway in cold tolerance by interacting with Skp1 in vitro (Kishi and Yamao, 1998). Several tests have been conducted using well-defined protocols under normal conditions in normal genetic background on formerly identified genes (Ahmad et al., 2021; Bashir et al., 2020).

\section{Genetic of nutrient-use efficiency}

Effective use of phosphorus and nitrogen nutrients has been one of the most essential targets of rice's genetic improvement (Zhang et al., 2009). Attempts were also made to recognize genes for the use of nutrients in rice and to regulate their consumption efficiency. For plant growth and development, nitrogen is an important and growth-limiting macronutrient. Two enzymes, glutamate synthase and glutamine synthetase integrate inorganic nitrogen into organic molecules (Stewart et al., 1980). Under anaerobic conditions, GS plays an important role for rice nitrogen assimilation and shows great affinity for $\mathrm{NH}^{4+}$ (Xie et al., 2010). Over expression of glnA increased the number of soluble protein in leaves and total nitrogen and amino acid contents in the plant, but with decreased grain production. Aspartate aminotransferase is a vital enzyme involved in carbon and nitrogen metabolism. In seeds, amino acids and protein contents significantly increased by over expression of EcAAT, OsAAT1 and OsAAT2 (Zhou et al., 2009). Osppc4 is a plant-type phosphoenolpyruvate carboxylase and is targeted to the chloroplast. At the vegetative stage, Osppc4 RNAi plants showed stunted growth when grown with ammonium as the nitrogen source than with nitrate (Masumoto et al., 2010).
$\mathrm{Bi}$ and his colleagues identified $\mathrm{N}$-responsive gene OsENOD93-1 from whole-genome Gene Chip analysis. OsENOD93-1 over expression significantly increased seed yield and shoot dry mass. Phosphate is absorbed into the roots of the plant through Pi transporters. The inorganic phosphate status of the plant can may be regulated by controlling or utilizing the activity of Pi transporters. An inorganic phosphate transporter OsPT2 is expressed favorably in the root stele and has low-affinity (Bi et al., 2009). Over-expression of OsPT2 brings out excessive amount of inorganic phosphate in shoot, on the other hand if the expression of OsPT2 is suppressed it reduces the transportation and absorption of Pi from roots to shoots. Molecular and genetic studies indicated that the physical interaction of OsPHO2 in roots and by upstream regulation OsPT2 is positively regulated by OsPHR2 (Charng et al., 2004). The role of OsPHR2 is inhibited by OsSPX1 which is regulated by the expression of OsPT2 in roots (Liu et al., 1999).

\section{Genetic of grain quality}

The rice grain quality consists of several attributes: cooking quality, eating quality, nutritional quality, milling quality, and appearance quality (Zhang et al., 2009). Eating and cooking quality are mostly determined by gel consistency, gelatinization temperature and amylose content of the grain starch (Xiang et al., 2008). Wx gene encodes granule-bound starch synthase I (GBSS I) which is required for the production of amylose in endosperm. Du1 gene encodes a pre-mRNA processing (Prp1) protein regulating the splicing efficiency of Wx (Cao et al., 2014; Zhang et al., 2009). Gelatinization temperature controlled by soluble starch synthase II (SSSII) encoded by ALK gene (Cao et al., 2014). During early grain filling, cell wall invertase enzyme regulates carbon partitioning encoded by GIF1 expressed in ovular vascular trace (Wang et al., 2008). Rice cooking and eating quality is controlled by the coordination of 18 starch synthesis-related genes (SSRGs) using candidate-gene association analysis approach and built a regulatory network underlying these characters (Chen et al., 2016).

$\mathrm{Fu}$ and Xue identified the genes that controlling starch biosynthesis using co-expression approach. Type I starch synthesis genes is negatively associated with APETALA2/ethylene-responsive element binding protein family transcription factor encoded by Rice Starch Regulator1 (RSR1) (Fu and Xue 2010). RSR1 gene over-expression suppressed the starch production genes, whereas in rsr1 mutants the amylose content was increased (Wei et al., 2017; Wu et al., 2019). Furthermore, RSR1 regulates seed size; yield isolated and characterized the genes controlling pericarp color, nutritional quality, storage time and rice fragrance. GS3 gene is greatly used in breeding for grain size and is an important QTL regulating grain length (Ying et al., 2018). Now a full-length cDNAs have been constructed for both Japonica and Indica rice and cDNA clones are available of about 40,000bp full-length (Liu et al., 1999; Takano et al., 2001). Using whole genome microarray analysis gene expression profiling 
in the complete rice life cycle has been accomplished (Kikuchi et al., 2003). Around the world several mutant libraries have been constructed by independent groups using chemical mutagens, retrotransposon or transposon tagging and T-DNA insertions. With the aim of conveying every gene's biological function till 2020, an International Rice Functional Genomics Project (IRFGP) has been proposed (Zhang et al., 2008).

Globally stated protein profiles of particular tissues can be studied due to the accomplishment of the draft sequence of the rice genome of two chief cultivars indica-type $c v$. and japonica-type cv. Nipponbare (Masumoto et al., 2010). In the future, the assigning of gene function of most rice genes will be the main interest for rice researchers where study of proteins at large scale will absolutely play an important role. Indeed, considerable progress has been made in developing the field of rice proteomics in the last decade. Several papers have also been published describing characterization and separation of proteins from numerous tissues (Gouveia et al., 2019; Lo et al., 2016).

\section{GTP-binding proteins}

Now the genome projects are enlightening that growing number of genes from several different organisms share relationships at the basic functional and structural level, thus expressing the 'tinkering' by which evolution was able to produced unique regulatory networks and recruit the raw materials to reconstruct new functions. In fact, the properties of specific genes have proven that many middle elements of the developmental pathways are highly conserved, particularly the proteins which act in signal transduction pathways. A notable example is the timers, molecular switches and GTPases that function by conformational changes resulting from the binding and hydrolysis of GTP by intrinsic activities (Kaziro et al., 1991; Takai et al., 1992). GTP binding proteins are conserved regulators of proliferation, cell motility, adhesion, apoptosis, polarity and cytoskeletal organization (Bischoff et al., 1999). They consists of large family of hydrolytic enzymes that can be subdivided into various groups: heterotrimeric G-proteins that are involved in hormonal and sensory signals, translational GTPases which are involved in ribosomal protein synthesis; cytoskeletal motor GTPases and tubulins, monomeric GTPases like the Ras superfamily which are liable for signal transduction cascades and motility, members of the SPR/SR family elaborate the translocation of peptides into the endoplasmic reticulum (Leipe et al., 2002). These enzymes mainly catalyze the alteration of GTP to GDP and inorganic phosphate. This is the main biological function of these enzymes (Zhu et al., 2002). GTP-binding regulatory proteins belong to a large family of guanine nucleotide binding proteins. These regulatory proteins are found in all eukaryotes. However, $G$ proteins have been classified as heterotrimeric or monomeric (small) GTPases on the basis of their size and composition of subunits (Vernoud et al., 2003).

\section{Genes for GTP-protein-signalling in plant genome}

The fully sequenced genome of the dicot angiosperm Arabidopsis thaliana encodes one gene product, GCR1, which has about 20\% similarity in short segments in its 7TM domain to the cAMP receptor CAR1 of Dictyostelium discoideum (Jeon and An, 2001). GCR1 substantially interrelates with G-subunit GPA1 of the plant (Dohlman et al., 1996). The structure of 7TM domain has been predicted by enzymes that are encoded by fifteen members of an Arabidopsis gene family labelled as fungal resistance $\mathrm{O}$ (MLO). These enzymes do not share arrangements with any other known GPCR. The 7TM domain structure has been biochemically confirmed for one MLO from oat (Reilly et al., 2021). Researches told that Arabidopsis consists of only one canonical GTP gene i.e. GPA1 (Ma, 1994), the RGA1 in rice (Ishikawa et al., 2005) and other diploid angiosperms (Williams and Friedman, 2002). The similarity between the sequence of the various mammalian $G$ proteins and single plant protein is $\sim 40 \%$. Regardless of low sequence identity between human subunits and plant, experimentation and modeling strongly support a genuine G-protein complex (Klopffleisch et al., 2011; Ullah et al., 2003). In spite of the apparent simplicity of GTP-binding protein signaling elements in plants, GTPases have been implicated in many plant phenomena (Jones and Assmann, 2004). Working with mutants has associated G proteins in control of seed germination, ion-channel regulation, cell division, light responses (Ouchi et al., 2001), cell elongation (Jeon and An, 2001; Jones and Assmann, 2004) and rejoinders to the gibberellic acid (GA), phytohormones abscisic acid (ABA) and auxin (Fujisawa et al., 2001; Jones and Assmann, 2004). Pharmacological studies have also implicated heterotrimeric GTPases in plant interactions with symbiotic bacteria (Kelly and Irving, 2003).

\section{Heterotrimeric G-proteins of plants}

In plants, the presence of heterotrimeric $G$ proteins was not indicated directly but only from indirect evidence; for example from kinetic analysis of GTPgS binding to microsomes, ribosylation of ADP or from purified plasma membranes (Ridley and Hall 1992). Numerous genes have been cloned from tomato, Arabidopsis, rice and soybean encoding $\alpha$-subunits of heterotrimeric $G$ proteins (Murai et al., 1991; Ren et al., 2005). They encrypt 44-kDa proteins of about 380 amino acids with correspondence to all known $\mathrm{G} \alpha$ subunits. The anticipated proteins show very high homology for non-protein $\mathrm{G} \alpha$ subunits and maximum homology to one another (70-87\%). For example, approximately the $50-75 \%$ alike to rat Gi1-3 and bovine transducin while about 26-36\% identical (Ouchi et al., 2001; Sasaki and Burr, 2000). The cDNA clones from barley have been recently isolated in which plant $\mathrm{G} \alpha$ subunits have been found while it has not yet been found in other well-characterized animal G $\alpha$ subclasses (Simon et al., 1991; Tezuka et al., 2019). All of the motifs are essential for GTP binding, $\beta$ and $\gamma$-subunits binding, are present in the known plant $\mathrm{G} \alpha$-like proteins. In addition, for translocation of $\mathrm{G} \alpha$ proteins to membranes an $\mathrm{N}$-terminal site for myristoylation 
is present and a specific arginine residue for cholera toxin mediated ADP ribosylation. These are also present in the known plant $\mathrm{G} \alpha$-like proteins (Hepler and Gilman 1992; Simon et al., 1991). $\beta$ and $\gamma$ subunits are chief components of heterotrimeric $G$ proteins while no plant Gg's have been reported yet. Several genes encrypting G $\beta$ subunits isolated from Arabidopsis and maize are approximately $40 \%$ identical to animal and yeast $\mathrm{G} \beta$ subunits that encode certain proteins (Kaibuchi et al., 1999; Kaziro et al., 1991). They contain seven fairly conserved WD40 motifs like that similar to other G $\beta$ subunits (Hallam, 1990). An important mechanism is provided by Heterotrimeric G-proteins due to which a specific signaling cascade is switched on or off to translate an incoming signal into a specific cellular response (Etienne-Manneville and Hall, 2002). These mechanisms consist of a possible regulator of $\mathrm{G}$-protein signaling proteins (RGS), the $\alpha, \beta$ and $\gamma$ subunits of the $G$ protein heterotrimer and heptahelical GPCRs (Ridley et al., 1992). Two major concepts are revealed by the study of these GTPases: The first one is that primarily $\mathrm{G} \alpha$ mediate some physiological responses, while others are generally mediated by G $\beta$ and G $\gamma$ (Parag-Sharma et al., 2016). Secondly, the main role of a given specific GTP- binding protein subunit responses to biotic and abiotic stresses and in plant developmental processes can vary in cell-type or developmental-stage-specific manner (Nakazaki et al., 2003; Peng et al., 2017). One GTP mutant can even show different phenotypic responses to the similar stimulus, depending on the specific cell or tissue under study (Ren et al., 2005; Sasaki and Burr, 2000). Over the last few years, the diversity of signal transduction through plant $G$ proteins has been studied enough and many researches are made on it; especially due to the rice and Arabidopsis genes identification and mutation that encodes specific GTP-binding protein components.

\section{The diversity of the small GTP-binding protein family}

All eukaryotic cells consist of a group of small GTPases ranging in molecular mass from 20 to $30 \mathrm{kDa}$ (Huang et al., 2009). All these proteins have almost similar amino acid structure and sequence identity because they are derived from a common ancestral gene (Eom et al., 2006). These proteins also work as a molecular switch. This facilitates the transport of vesicles to their target, transduction of signals across membranes and regulating cell proliferation (Xing et al., 1997). They bind to GTP and are turned on while they are turned off by hydrolyzing GTP to GDP (Kiyosue and Shinozaki, 1995). Small GTPases can be divided into five subfamilies, on the basis of amino acids function and similarity: Rho/Rac, Rab/Ypt, Ras/Ras-like, Arf/Sar and Ran/TC4. The subfamily Rho/Rac is involved in regulation of growth factor-induced membrane ruffling and is confined to cytoskeletal organization (Verma et al., 1994). The Rab/Ypt family is involved in Identification of Rab proteins, vesicular transport, in identification of Ras-like gene in yeast (Kaneko et al., 2004; Kikuchi et al., 2003). Different genes were isolated by (Pfeffer, 2017), encrypting Rab protein. He found that different Rab proteins are localized on diverse compartments in the endocytic and secretory pathways. Among all Ras is the best defined small GTPase. Ras/Ras-like proteins are thought to be involved in regulation of cell differentiation, cell growth and signal transduction (Kiral et al., 2018). The subfamily Ran/TC4 is present in the nucleus. These proteins are essential for DNA synthesis and transport of proteins into the nucleus. Arf/Sar subfamilies are probably $2.60 \%$ similar to each other, having different functions. Aspenstrom proposed that the amino acid sequence of the Arf/Sar proteins are distantly related to the Rab/Ypt family (Aspenström, 2019). Patino-Medina and his colleagues acknowledged and refined ARF as a protein cofactor (Patiño-Medina et al., 2019). ARF is essential for ADP ribosylation of $\alpha$ subunit of heterotrimeric $G$ proteins. It is associated with Golgi membranes (Van Acker et al., 2019). Arf is also supposed to be involved in the vesicle budding process, which is regulated by heterotrimeric $G$ proteins (Bauerfeind and Huttner, 1993).

\section{Accessory factors associated with small GTP- binding proteins}

All GTP-binding proteins undergo GTP-bound and GDP-bound states. This switch is regulated by a number of accessory proteins (Bischoff et al., 1999). GAP enzyme accelerates GTP hydrolysis by increasing the intrinsic GTPase activity linked with GTP-binding proteins; otherwise, the GTP hydrolysis rate is very low (Hepler and Gilman, 1992; Kiral et al., 2018). GEF mediates the replacement of GDP with GTP, causing GTPase to become active. GDI prevents the separation of GDP and inhibits the GDP bound form of Rab proteins from binding to membranes (Kishi and Yamao, 1998; Valle-Maldonado et al., 2020). The GAP protein of Ypt6p initiates the GTPase activity of Ypt6p but not that of Rab proteins. Muller and his colleagues found that Yeast Dss4 protein have GEF activity for Sec4 and its mammalian homolog. Mss4 protein has GEF activity for Rab3a and Yptlp as well as for Sec4p (Müller and Goody, 2018). Identified GDI dissociation factor, a membrane component has been implicated in the recruitment of specific Rab proteins into the vesicles. This protein causes separation of the Ritb-rab GDI complex and thus stimulates binding of the Rab protein to the membrane (Homma et al., 2021). Zerial and McBride identified a number of other essential proteins of the transport machinery other than Rab protein (Zerial and McBride, 2001). Both yeast and mammalian cells require SNAPs and NSF for vesicle fusion. Nichol and his colleagues isolated membrane proteins main extract that bind to SNAPs and suggested that these proteins mediates the fusion of synaptic vesicles (Nicol et al., 2018). These findings have led to a general model of vesicle transport and fusion, termed the SNARE hypothesis (Adnan et al., 2020).

\section{Small GTP-binding proteins in plants}

Small GTPases have the ability to bind to nucleotides guanosine diphosphate and guanosine triphosphate, when resolved by SDS-PAGE and shifted to nitrocellulose filters. This property has endorsed scientists to identify the existence of small GTP-binding proteins in microsomal 
membranes and in plant extracts and in thylakoid (Nishiyama et al., 2018). Two important proteins of 24 and $28 \mathrm{kDa}$ from plasma membranes of soybean and two of 26 and $28 \mathrm{kDa}$ from root nodule peri-bacteroid membranes bind to GTPyS (Zbell et al., 1990). Ding et al. (2018) suggested the character of small GTP binding protein in cell elongation stimulated by auxin. The growth of IAA hormone in rice increases the binding of GTPyS to vesicles in vitro. A significant amount of a $28-\mathrm{kD}$ GTP-binding protein was translocated from the Endoplasmic reticulum and Golgi apparatus to the chloroplasts and plasma membrane when cells of the green alga (Dunaliella salina) were subjected to hypo-osmotic swelling (Hua-Ying et al., 2019; Wang et al., 2017).

The small GTPase superclass can be divided into two main classes on the basis of their sequences and structures: SIMIBI class (the signal recognition particle, BioD and MinD-like ATP-binding proteins) and TRAFAC class (the translation factors). The SIMIBI class has been found involved in membrane transport activity, localization of proteins, a set of metabolic enzymes with phosphate transferase activity or kinase activity and in splitting of chromosomes (Leipe et al., 2003). On contrary, the TRAFAC (translation factors) class belonging to the P-loop GTPases, is a novel group of G-proteins, initially identified by analyzing fully sequenced bacterial genomes and includes proteins involved in cell motility and translation. The TRAFAC class is divided into seven families: Era (E. coli Ras-like protein), TrmE, Hflx, YfgK, OBG, YihA, and classic translation factor family (Verstraeten et al., 2011).

Several techniques have been applied for the extraction of various cDNAs encoding small GTPases from plants. Degenerative oligonucleotides have been used for the extraction of various cDNAs. These degenerate oligonucleotides refer to one of the consent sequences in the GTPase superfamily. A SARZ homolog cDNA from Arabidopsis was isolated with the help of plant cDNA library along with complementation of yeast mutants (Van Acker et al., 2019). A rabll homolog cDNA (rgpl) was cloned from rice using subtraction screening strategy. While isolation of homologous cDNAs like Rab7 from Vigna aconitifolia is now also possible by low-stringency screening method using heterologous probes (Feng et al., 2014) and rgp2 from rice (Chen et al., 2015). Identified Rab5 homolog clone and sequenced 130 randomly selected clones from a maize leaf cDNA library (Horiuchi et al., 1997). Rhal protein has been found to be localized to early endosomes and highly homologous to Rab5. Its expression exposed by rhal promoter driven 0 -glucuronidase activity, was found mainly in the guard cells and also in the stipules, root tips, young leaves and in the receptacles of flowering Arabidopsis plants (Luck et al., 1998). A gene in Arabidopsis thaliana encodes a Rab6 homolog that is localized to trans-Golgi and media1. It complemented a yeast ypt6 mutant, indicating its functional conservation. A dominant expression of a Rab6 mutant failed to prevent vesicular transportation through mammalian Golgi and Ypt6 mutant is not necessary for cell proliferation (Chen et al., 1998). Sano and Youssefian isolated rgp1 a rabll homolog cDNA from rice and found that expression of this gene is decreased in azaC-treated rice dwarfing plants (Sano and Youssefian, 1991). The expression level of a second rabll homolog rgp2 is not affected by azaC treatment (Youssefian et al., 1993b). Expression of sense and antisense rgpl in transgenic tobacco showed reduction in apical dominance and enhanced tillering (Sano et al., 1994). Identified two Rab homologs, a Rabll homolog Np-ypt3 and a rab5 homolog Nt-rab5 in tobacco. These genes have similar expression patterns; in flowers the expression is highest and undetectable in leaves (Saalbach and Thielmann, 1995). Pea isolation offered the extraction of a cDNA of rab7 homolog and of a gene which is involved in the regulation of microfilament organization called Rhol gene (Nicol et al., 2018; Ridley et al., 1992). The expression of rab7 is improved significantly during nodulation. The level of rab7 mRNA rises twelve times than that in leaves and root meristem. This corresponds with the endocytosis of Rhizobium in root nodules and with the membrane proliferation which in return decreases the expression of these proteins by antisense cDNAs under the control of nodule-specific promoters. This significantly affects the biogenesis of symbiotic organelle and the nodule development (Nishiyama et al., 2018). A Rabl/Yptl homolog was identified in maize coleoptile cells that consisted C-terminal Cys motif and all the consensus sequences (Takai et al., 1992) Isolated cDNA clones encoding Rabl and Rab7 homologs from soybean and V. uconitifolia root nodules. The yeast yptl mutant is likely that of the plant Rabl (Simon et al., 1991).

\section{Biochemical studies of plant G-proteins and their involvement in plant signaling}

\subsection{Detection of GTP-binding proteins}

The mechanism of signal transduction pathway in plants is not yet known much. Researchers are being carried out their experimentations on it. However, still a little information is known. Plants cellular response is affected by various signals from both the environment and from other cells. GTP-binding proteins play an important role in cells of animals and simple eukaryotes. Likewise, G-proteins may influence and play an important role during signal transduction pathway in plants. In vitro, there are number of ways to detect G-proteins. One of which is GTP-binding assay. GTP-binding assay is one of the main and widely used techniques to detect G-proteins. This technique usually uses one of the non-hydrolyzable GTP analogues like GTP7S. It detects small GTPases, other G-proteins and heterotrimeric G-proteins. The binding activities present in plant extracts can be quite complex (Takagi et al., 2007; Tyagi and Mohanty, 2000). The small GTPases and $\alpha$ subunit of heterotrimeric GTP-binding proteins have basic GTPase activities. The lack of preciseness of this process for some specific type of GTP-binding proteins causes some major limitations to it (Ueki and Nishii, 2008). Besides, GTPase activity and GTP-binding assay method; Bacterial toxins are being used that causes ADP ribosylation of some $\alpha$ subunits of heterotrimeric G-proteins. Pertussis and cholera are the generally used toxins (Vernoud et al., 2003). These toxins and as well as radioactive $\mathrm{NAD}^{+}$may detect susceptible 
G-protein alpha subunits, which works as donor of ADP ribose group (Wang et al., 2008). Transducins and Gi's are a type of $\mathrm{G} \alpha$ subunit sensitive to the pertussis toxin. They have a cysteine residue close to the carboxy terminus (Wilson et al., 1996; Xiang et al., 2008). ADP ribosylation by cholera toxin is very complex while ADP ribosylation by pertussis toxin proved to be sensitive for a subset of $G$ protein e subunits. A soluble factor, ARF which is a small GTPase highly stimulates the ADP ribosylation by cholera toxin. This ARF is activated by the binding of GTP or analogues of GTP (Zerial and McBride, 2001). In addition, ADP-ribosylated arginine residue is preserved all among G-protein e subunits. G-protein e subunit is competently modified by cholera toxin while others may be modified under specific conditions (Xing et al., 1997; Ying et al., 2018). However, some proteins work as substrates for ADP ribosylation by cholera toxin but comparative to Gs they are slowly ribosylated and sometimes dominate the labelling arrangement when abundant (Yuan-Yuan and Zhang, 2006).

The effect of ARF and other proteins can be modified by cholera toxin make it useless, desirable and more prone to artifacts. The toxins are only useful to identify the presence of certain classes of $G$ proteins in an extract (Ying et al., 2018). GTP binding proteins which are not substrates for the toxin catalyzed ADP ribosylations (Wu et al., 2019). Immunoblot method using antisera against peptides from known $G$ proteins have also been very powerful (Hsing et al., 2007). A number of groups have used antibodies raised against a conserved peptide of the e subunit of heterotrimeric $G$ proteins (James Junior et al., 1995). By studying the given analyses in association with GTP-binding proteins provided strong indication for the existence of $G$ proteins in plants. There are certain limitations in studying the antibodies i.e. that it requires cross-reactivity among plant proteins and antibodies (Huang et al., 2009). By using 35S-labeled GTP binding in solution, GTP-binding activities were detected in the thylakoid membranes of spinach (Spinacea oleracea) leaves (Izawa et al., 1997) and in membranes of rice coleoptile (Jones et al., 1994). GTPase activities were found in the eyespot of the green alga (Chlamydomonas reinhardtii) (Xing et al., 1997) and in membrane extracts from maize roots (Wang et al., 2017). GTP-binding activities and substrates for ADP ribosylation catalyzed by pertussis toxin were detected in gel filtration fractions of extracts from pea (Pisum sativum) and Lemna paucicostata (Schneider et al., 2005). A filter assay has been used to uncover small GTP binding proteins in the green alga (Sasaki and Burr, 2000), in microsomes of zucchini (Cucurbita pepo) hypocotyl (Reilly et al., 2021), in chloroplast outer envelope membrane and nuclear envelope from pea (Youssefian et al., 1993a). In 2015 , in the cytosol of pea plumule cells ARF-like protein was discovered by Rout and Panigrahi. The amalgamation of immunological analysis and GTP-binding studies along with antibodies showed that the known $\mathrm{G} \alpha$-subunits have identified potential heterotrimeric $G$ protein subunits from barley (Hordeum vulgare) (Zbell et al., 1990), Arabidopsis, zucchini (Cucurbita pepo) (Roy et al., 2019), broad bean (Vicia faba) and Commelina communis (Zhou et al., 2009).
There have been identified a $24 \mathrm{kDa}$ GTP-binding protein in etiolated seedlings of oat (Avena sativa) by using western blot analysis using anti-G antibodies, GTP-binding assay and ADP ribosylation with cholera toxin. This protein is smaller than any known heterotrimeric $G$ protein subunits (Chen et al., 1998; González-González et al., 2017) identified two small GTP-binding proteins ( 28 and $30 \mathrm{kDa}$ ) in rice coleoptile using anti-G antibodies and a filter GTP-binding assay. Recognized aleurone protoplasts of 22 and $24 \mathrm{kDa}$ in barley by using anti-ras antibodies. It is possible that the anti-G antibodies cross-react with small $G$ proteins and the conditions used for ADP ribosylation by cholera toxin permit the modification of small $G$ proteins (Bischoff et al., 1999; Bishop et al., 1996). The complete identification and characterization of these proteins must await further molecular studies.

\subsection{G-protein involvement in plant signaling pathways}

The interaction of GTP-binding proteins with receptors, effectors and GTP/GDP takes place at specific points of a cycle. Therefore, alteration at one point in the cycle affects the succeeding points. In many cellular processes pertussis bacterial toxins, GTP analogues and cholera were helpful in examining the involvement of GTP-binding proteins. GTP analogues can easily probe $G$ protein function, especially GTPvS are used often. GTP analogues affect both small GTPases and heterotrimeric G proteins (Ying et al., 2018; Zbell et al., 1990; Zhou et al., 2009). Extracellular signals activated by a receptor-ligand complex are often mediated by heterotrimeric $G$ proteins. These signals are activated by the exchange of a bound GDP for a GTP (Zerial and McBride 2001). The presence of a $G$ protein stimulates the GTP binding in a signaling pathway (Xiang et al., 2008). Exchange of GDP to GTP causes the activation of heterotrimeric $G$ proteins. The intrinsic GTPase activity of the c-subunit causes the hydrolysis of GTP to GDP and phosphate, and due to this the activation of heterotrimeric G proteins is reduced (Xing et al., 1997). GTPase Activating Protein (GAP) highly increases the activity of small GTPases (Yu et al., 2002). The most powerful activators of $G$ proteins are GTP analogues like GTP7S and GMP-PNP and these GTP analogues cannot be hydrolyzed (Xing et al., 1997), then Sometimes guanine nucleotides can be used to stimulate the signal in generating the response, especially when a signal is characterized for a particular cellular process for example response to light (Wang et al., 2017).

Bacterial toxins can also be used to study and analyze $G$ protein function in various cellular processes (Yuan-Yuan and Zhang 2006). Both GTP and GDP bound forms of G proteins can be ADP-ribosylated by cholera toxin and it may inhibit intrinsic GTPase activity (Van Acker et al., 2019). The light-stimulated signaling pathways of GTP binding proteins explored by using both GTP analogues and bacterial toxins. In Lemna plant, a single eight-hours period of darkness induces flowering. Before Lemna plant extracts were prepared, they were kept in eight hours single period of darkness while $20^{\circ}$ by red or far-red light inhibited GTP binding. But, the GTP binding was not affected by blue light (Verma et al., 1994; Vernoud et al., 2003). The red receptor phytochromes involved in the 
regulation of one or more $G$ proteins (Terryn et al., 1993). There was seen similar inhibition with red light and far red light, which have opposite effects on phytochromes. The exposure of far-red light for four-minute inhibited GTP binding while exposure of red light for two-minute stimulated GTP binding in the nuclear membrane of pea. Similarly, the observed etiolated oat seedlings showed GTP binding with membranes was stimulated by red light (Lin et al., 2006). The GTP analogues GTP7S and Gpp(NH)p simulated the effects of the light receptor phytochrome A on light-dependent synthesis of anthocyanin. Moreover, GTPase activity and GTP-binding activity in plasma membranes of etiolated pea seedlings is stimulated by blue light. In the absence of GTP and blue light, pertussis toxin ADP-ribosylated a $40 \mathrm{kDa}$ protein in plasma membrane (Chin et al., 1999; Dufresne et al., 2008).

The blue light signal transduction may be carried out by a heterotrimeric $G$ protein in etiolated pea seedlings. The intrinsic GTPase activity of the c-subunit causes the hydrolysis of GTP to GDP and phosphate, and due to this the activation of heterotrimeric $G$ proteins is reduced while GTPase Activating Protein (GAP) highly stimulates GTPase activity in small GTPases (Agrawal et al., 2001; Chandlee, 1990).

\subsection{G-protein components in Arabidopsis and rice}

Proteins extracted from various plant species resembles to that of mammalian G-protein components. In Arabidopsis and rice, a single copy gene encodes $\mathrm{G} \alpha$. Labelled as GPA1 in arabidopsis or RGA1 in rice. Correspondingly, $G \beta$ is also encoded by a single copy gene, labelled as AGB1 or RGB1, respectively. Two G $\gamma$ genes RGG2 and AGG1 were isolated from Arabidopsis and rice (Lin et al., 2006; Liu et al., 1999). No plant gene has been found that is highly homologous to metazoan GPCRs (Miyao et al., 2003; Moon et al., 2006). GCR1 is a GPCR-encoding candidate gene in Arabidopsis. It encodes a protein that has some GPCR sequence similarity and a predicted heptahelical structure that is the hallmark of GPCRs (Mathieu et al., 2009; Murai et al., 1991). The The genome of Arabidopsis contains only one member of the RGS family i.e; RGS1 (Kaeppler et al., 2000). The basic pattern of $G$ protein signaling in mammals is similar to that appears in plants. He described it on the basis of both modeling and research (Kaneko et al., 2004; Kikuchi et al., 2003). Plasma membrane of plant cells consists of all RGS1, GCR1, G $\alpha, \mathrm{G} \beta$ and G $\gamma$ (Kolesnik et al., 2004; Kumar and Hirochika 2001). G $\beta$ bounds strongly with $\mathrm{G} \gamma$ subunit in rice and Arabidopsis when performing co-immunoprecipitation experiments and yeast two-hybrid assays (Izawa et al.,1997).

In rice, gel-filtration experiments have confirmed that $\mathrm{G} \beta$ and $\mathrm{G} \gamma$ dimers associate with $\mathrm{G} \alpha$. This association is disturbed by a non-hydrolysable form of GTP, GTPgS, which is predicted to conserve the activated conformation of $\mathrm{G} \alpha$ (Lin et al., 2006; Luck et al., 1998). The first conclusive evidence showed that GCR1 physically interacts with $\mathrm{G} \alpha$ by using in vitro co-immunoprecipitation as well as split-ubiquitin yeast two-hybrid assays (James Junior et al., 1995). The interaction of RGS1 showed with both a constitutively active GPA1 and wild type GPA1. The carboxy-terminal domain of AtRGS1 exert G $\alpha$ AP activity on a yeast $\mathrm{G} \alpha$. Plants and other eukaryotic organisms possess major differences between there $G$ protein components. The similarity of amino acid sequence of the related genes and proteins is restricted and plant genes encoding each of the different component are lesser than in other eukaryotes (Mazier et al., 2007; Murai et al., 1991).

\subsection{Era-like GTP binding protein}

Reticular activating system proteins also known as Ras-like protein are GTP-binding protein confers binding activity with RNA, Homologues of these proteins were primarily found in E. coli and hence, it is called ERA (E. coli Ras-like proteins) and later on, these proteins have been discovered in several organisms such as human, mouse and Antirrhinum majus (Gale and Devos 1998; Hamer et al., 2001).

Cell division can be blocked by the depletion of prokaryotic ERA but the segregation of chromosomes cannot disturbed (Courage-Tebbe et al., 1983; Dias et al., 2008). In E. coli, the DNA sequence which is responsible for the synthesis of ribonuclease were found instantly upstream of the gene (Era) contain 316 amino acids in its polypeptide chain (Chin et al., 1999; Chopra et al., 1999). There is a great similarity present between Ras-like proteins of yeast and E. coli (Charng et al., 2004; Chuck et al., 1993). A Ras-like protein of yeast comprises of 316 amino acids residues, another Ras-like protein found in E. coli also known as ERA confers very low activity to hydrolyze GTP (Camacho et al., 2003). E. coli Ras-like proteins are very important in many biological processes such as cell division (Kunze and Weil 2002; Mazier et al., 2007), pleiotropic pathways like metabolism of fatty acids and carbon, adaptation to resist against temperature stress to promote growth of cell and its sustainability (Luck et al., 1998). Two preserve domains are present in ERA, in which one domain binds to the $30 \mathrm{~S}$ ribosomal subunits and the 16S rRNA of E. coli called KH (K Homology) domain while the other domain is similar to RAS called GTPase domain associated with the TRAFAC group of (Koonin and Galperin 2002; Miyao et al., 2003).

Antirrhinum majus was first plant species in which GTPase was first found homologus to ERA that is only active in cell division or active metabolism of cells. A study of DNA database suggested that DNA sequences that are similar with ERA are present in numerous other living organisms such as human, Drosophila, Caenorhabditis elegans and mouse (Britton et al., 2000). Further studies suggested that GTP is hydrolyzed into GDP by ERA and in vitro hydrolysis rate ranges from 0.3 to $17.5 \mathrm{mmol}$ of GTP/min/mol (Martienssen, 1998; Miyao et al., 2007).

The ERA is a significant GTPase protein of $E$. coli that is involved in many cellular activities. They described the mechanism of hydrolysis and binding of ERA guanine nucleotide binding but the exchange rate of guanine nucleotide have not ever been published. They further suggested that functional models of ERA reveal the rapid conversation of nucleotides and therefore, GTPase activity is essential to ERA (Giroux et al., 1994; Hamer et al., 2001). Only a small number of the Obg and Era like GTP-binding 
proteins have been characterized through experimentation but function of these proteins remains unknown, the available data revealed that many of them are involved in cell growth. A broadly distributed bacterial subfamily of GTPase was discovered with the current explosion of available genome sequence data which were represented by the E. coli ERA and the B. subtilis Obg proteins. Nine genes involved in encoding of GTP-binding proteins of the Obg/Era family were identified during the survey of complete genomic sequence of B. subtilis (Goff et al., 2002; Hirochika, 1997).

The GTPase that are similar to ERA exhibits the binding activity with RNA is present in various organisms such as A. majus, mouse and humans. Reduction of prokaryotic Era affects the cell division and consequently blocked the division of cell but the segregation of chromosomes cannot disturb. Although, the biological functions of eukaryotic Era are still unidentified (Goff, 1999; Greco et al., 2001). The three GTPase, Obg, LepA, and Era of M. tuberculosis and expressed in Escherichia coli and found that Obg, LepA and Era protein are involve in the activity of GTPase that help scientists to analyze the physiological importance of these proteins related to pathogenesis (Jones et al., 1994; Kolesnik et al., 2004). Firstly, characterized an Era-like GTP binding protein in filamentous fungi. In Magnaporthe oryzae commonly known as Rice blast fungus, in which they found a gene responsible for the synthesis of protein similar to E. coli Ras-like GTP binding protein. They proposed that mature terminal of a protein found in the arbuscular mycorrhizal fungi (Glomus intraradices) called the Gin1 protein is more similar to this protein and during the labelling of carboxy-terminally with GFP (green fluorescent protein) it become limited to the nucleus. In Aspergillus nidulans, amino-terminal tagged with GFP were expressed and they observed polarity defects due to limitations to the cytoplasm (Jiang et al., 2004; Kempin et al., 1997; Larkin and Scowcroft, 1981).

In higher classes of Plants, studied the classification and biological functions of Double Era-like GTP binding proteins. Both C-terminal domain (CTD) and GTP-binding domains or GD are back to back repeated in double ERA-like GTP binding that is closely similar to the domain involve in the binding of RNA also known as K-homology domain. The results suggested the vital role of DER in the processing of chloroplast rRNA and synthesis of ribosome in higher classes of plants with complex genome (Komatsu et al., 2003; Koonin and Galperin, 2002). The Era/Obg proteins of P-loop GTPase superclass are conserved in several prokaryotes and eukaryotes. Basic cellular processes such as ribosome biogenesis signal transduction and translation are critically regulated by some of these proteins. Although, a genome-wide overview of the Era/Obg GTPase genes in plants have not been provided yet (Saika et al., 2005; Schwarz-Sommer et al., 1985). It has been screened and identified a single mutant gene encoding for the GTP-binding protein Era in cyanobacteria that contain an insertion in it and revealed the importance of this protein in the metabolism of hydrocarbon and fatty acid along with the determination of the cell size. Improvement in the production of biofuel precursors is possible through the results showed that the GTP-binding protein Era can be used as a novel target for further (Koncz et al., 1989; Kunze and Weil, 2002).

The newly recognized small GTP-binding protein, Nucleolar GTPase 1 (NOG1) that have important role in plant immunity against bacterial attack (Larkin and Scowcroft 1981; Luck et al., 1998). The outcome of this research provided valuable evidences on the new functional role of small GTPase, NOG1, in early plant defense in response to bacterial attack as well as in guard cell signaling. The Era-like GTP binding proteins are actually encoded by nuclear DNA and hence called nuclear-encoded GTP binding proteins contain two conserved domains, first one is GD (GTP binding domain) and second is $\mathrm{KH}$ (K Homology) domain (Luo et al., 1991; McCarty et al., 1989). It is involve in early development of seed in higher plants such as Antirrhinum majus. Conclusion of his studies suggested that early development of seed indorses by Era-like GTPase affects the synthesis of mitochondrial proteins and maturing of small subunit of ribosomes in the process of Arabidopsis. ERA-like GTPase is well-preserved in many organisms such as eukaryotes, bacteria and archaea, ERA-like 1 (ERAL1) is one of its nuclear-encoded variant present in the mitochondrial matrix of humans matrix (McClintock 1951; Murai et al., 1991). They revealed that mitochondrial 12S rRNA is attached with ERA-like 1 (ERAL1) to indorses maturation of smaller ribosomal subunit of mitochondria, while cytoplasmic ribosome rRNA is not binds with it.

The siRNA is used to induce mutations in the gene encoding for ERAL1 which causes cell death because mutated gene promotes the synthesis of reactive oxygen species (ROS) and protein translation inhibition in mitochondria. The consequences of the study specified the importance of ERAL1 in cell viability and in the constitution of small ribosomes (Naito et al., 2009; Nakagawa et al., 2000).

\subsection{Era-like GTP binding proteins in plants}

Antirrhinum majus is the first plant species in which ERA-like GTP binding proteins were discovered in cell division or metabolically active cells (Ross-Macdonald et al., 1999; Suzuki et al., 2001). It was anticipated that aminoterminal sequences of $E$. coli related GTPase is responsible to target the mitochondria, development of seeds are detained by the introduction of mutation in E. coli related GTPase allele through site selected transposon mutagenesis (Neuvéglise et al., 1998; Ouyang et al., 2007). In Arabidopsis, there were two variants of ERG genes identified in the Genomic data, first gene was found in in chloroplast were named as AtERG1 and other gene were found in mitochondria were named as AtERG2 (Schnell and Lefebvre, 1993; Schwarz-Sommer et al., 1985).

Jeon and An revealed two continuously repeated GTPase domains in double Era-like GTP binding protein and another domain was similar to $\mathrm{K}$ homology domain which was specialized in RNA binding, these domains were present in Nicotiana benthamiana so were named as NbDER. It was bound with to $16 \mathrm{~S}$ and $23 \mathrm{~S}$ ribosomal RNAs to perform its primary function which was GTPase activity by comprising in the association and maturation of 
50 ribosomal subunit of chloroplast and hence, found in the nucleoids of chloroplasts. The activity of Plastid-encoded ribosomal RNAs is diminished by introducing mutation in NbDER leads to the disruption of chloroplast synthesis reason for the yellowing of leaves and hence, chloroplast starts accumulating of the precursor rRNAs (Jeon and An, 2001). The N-terminal sequence dependent Arabidopsis thaliana Era Gene 2 were found attached with 18S RNA of mitochondria. Although, there is no such evidences that can describe the mechanism of Arabidopsis thaliana Era like genes in the synthesis of ribosomes and processing of rRNA responsible for the synthesis of organelle. Development of seeds rigorously affected by introducing T-DNA in the lines of Arabidopsis thaliana Era like gene 2 that can further cause arrest of zygote at 1.5 DAP and leads to seed abortion at 2.0 DAP in aterg2-1 +/-. These results suggested the function of Arabidopsis thaliana Era like gene 2 in controlling the primary development of seeds by maturing Ribosomes and mitochondria for the synthesis of important proteins (Charng et al., 2004; Chin et al., 1999).

A vital protein is synthesized from E. coli Era genes capable of binding with GDP and GTP. ERA genes are greatly associated with a broad spectrum of cellular activities (Jeon and An 2001; Jiang et al., 2003). Many phonotypical traits can be suppressed by introducing mutations in ERA such as mutation in a dnaG gene responsible for the temperature sensitive and thus, ERA is very essential in many biological process such as chromosomal segregations and DNA replication. Induction of mutation in G2 domain of ERA causes defects in its functioning in carbon metabolism because it became unable to use specific tricarboxylic acid intermediates which is a sole carbon source. Mutated ERA can inhibit the genes responsible for phosphotransfer system (PTS) because of it is directly associated with phosphoenolpyruvate sugar phosphotransfer system (Hirochika et al., 2001; Ipek and Simon 2002). The processes of kinetic analysis such as ERA mediated hydrolysis, binding and exchange of Guanine nucleotide by using the variants of MANT Guanine nucleotide. They demonstrated the statistical values of ERA based hydrolysis and equilibrium binding constant $(K D)$ and found it similar to the values of unmodified MANT Guanine nucleotides. In contrast with other Ras protein, the rapid speed of ERA to exchange Guanine nucleotide is much similar to another protein known as Caulobacter crescentus protein (CgtA). They proposed that the GTPase activity is intrinsic to the rapid activity of ERA to exchange nucleotides (Hsing et al., 2007; Ishikawa et al., 2005).

Rice researchers have made massive innovations, but there is still some areas that connects phenotypic traits to genotype and huge knowledge is require to fill this gap to bring desired verities for the sustainability of agriculture. The main objective of rice functional genomic research is to identify the function of each gene of rice genome and to find the role of efficient diversified alleles in Rice genetics, implementation of this knowledge to improve the genome of rice to identify beneficial genes and beyond (Haseeb et al., 2020; Hirochika et al., 2004; Kikuchi et al., 2003).
Immunoelectron microscopy and Sub-cellular fractionation have revealed the location of Era, it is situated at the cytoplasmic surface of the inner membrane and hence called peripheral membrane protein. The process responsible for the interaction between Era and its membrane is still not defined either the mechanism of interaction is similar to the membrane signaling of GTPase. Nevertheless, the biological functions of eukaryotic Era like GTPase are not identified.

RGA1, RGG1, RGB1 and RGG2 are four kinds of rice genes encoding heterotrimeric $G$ protein subunits. Their expression in epidermal cells is almost similar (Jeon and An 2001; Kaneko et al., 2004).

107 types of small G-proteins found in rice were divided into six families (Jiang and Ramachandran, 2010). These families are named as Rab, Arf, Rop, Ran, Ras, and other GTPase genes. Among these, Other GTPase genes family comprising GTP-binding protein synthesis factor are up-regulated while two Rop and one Rab genes are down-regulated the above adventitious plant root primordia in epidermal cells as compared to other epidermal cells. In addition, 60 GAP genes of rice have been identified, which are categorized into the following subgroups: RabGAP, RopGAP, other GAPs, ArfGAP and RanGAP (May and Martienssen, 2003; Miyao et al., 2003). Among these subgroups, other GAPs family member and RopGAP10 were down-regulated above root primordia of epithelial cells. Furthermore, rice genome consisted of three GDI genes among which one was down-regulated above adventitious roots in epidermal cells, whereas five GEF genes of rice were expressed correspondingly in epidermal cells with above adventitious roots (Kunze and Weil, 2002). Microarray analysis bioinformatically predicted eleven GPCR genes out of thirteen from rice (Koonin and Galperin, 2002; Kumar and Hirochika, 2001). The transposable elements usually have millions of copies in the genomes of organisms which caused stable variations and development of mutant lines in crop plants. For example, there are around a million of copies of Alu sequences in human genome are present which have specific functions in the gene regulation and maintenance of cellular biochemical and physiological activities. These transposable elements have ability to move within the genome due to which these sequences can add, delete, replace or even caused to duplicate the sequences of genes within the genome which ultimately caused genetic diversity and mutations in population of same species of plants and animals.

\section{Conclusions}

The use of induced mutations for studying the mutagenesis in crop plants is very a common as well as a promising method for screening crop plants with new and enhanced traits for the improvement of crop plant yield and production. The utilization of insertional mutations through transposons or jumping genes usually generates stable mutant alleles which are mostly tagged for the presence or absence of jumping genes or transposable elements. The use of transposable elements may be used 
for identification of mutated genes in crop plants and even for stable insertion of transposable elements in mutated crop plants.

The jumping genes or transposable element sequences of genomic DNA caused major changes and mutations in the genomes of plants, animals and microbes to make them able to survive under varying environmental conditions and caused to evolve into a new species of crop plants with new trait and functions.

The insertion of nDart1 transposable element in rice revealed variations in the anatomy, structural, functional and biochemical changes in rice for the development of mutant lines. The nDart1 including high potential and autonomous genetic element within the genome of rice lines, which have various possible applications of nDart1 elements for the development of a novel gene targeting for its higher potential for contribution to produce natural and stable genetic variations with mutant form in rice lines. However, there is need for further molecular and genetic elucidation for studying the regulation of nDart1 transposable elements or jumping genes which may facilitate the identification and development of various new transposable elements for gene tagging systems, and which may also contribute for understanding functional genomics and rice breeding for improvement of yield and production of rice.

\section{Acknowledgements}

This project was supported by the Open Project Program of Joint International Research Laboratory of Agriculture and Agri-Product Safety, the Ministry of Education of China, Yangzhou University (JILAR-KF202004)

\section{References}

AARTS, M.G., DIRKSE, W.G., STIEKEMA, W.J. and PEREIRA, A., 1993. Transposon tagging of a male sterility gene in Arabidopsis. Nature, vol. 363, no. 6431, pp. 715-717. http://dx.doi. org/10.1038/363715a0. PMid:8390620.

ADNAN, M., FANG, W., SUN, P., ZHENG, Y., ABUBAKAR, Y.S., ZHANG, J., LOU, Y., ZHENG, W. and LU, G.D., 2020. R-SNARE FgSec22 is essential for growth, pathogenicity and DON production of Fusarium graminearum. Current Genetics, vol. 66, no. 2, pp. 421-435. http://dx.doi.org/10.1007/s00294-019-01037-y. PMid:31667538.

AGRAWAL, G.K., YAMAZAKI, M., KOBAYASHI, M., HIROCHIKA, R., MIYAO, A. and HIROCHIKA, H., 2001. Screening of the rice viviparous mutants generated by endogenous retrotransposon tos17 insertion. Tagging of a zeaxanthin epoxidase gene and a novel OsTATCGene. Plant Physiology, vol. 125, no. 3, pp. 12481257. http://dx.doi.org/10.1104/pp.125.3.1248. PMid:11244106.

AHMAD, M., ALI, Q., HAFEEZ, M. and MALIK, A., 2021. Improvement for biotic and abiotic stress tolerance in crop plants. Biological and Clinical Sciences Research Journal, vol. 2021, no. 1, pp. e004-e004.

AKRAM, A., ARSHAD, K., HAFEEZ, M.N., and AHMAD, A., 2021. Cloning and expression of universal stress protein 2 (USP2) gene in Escherichia coli. Biological and Clinical Sciences Research Journal, vol. 2021, no. 1, pp. e002.
ALI, M., RAFIQUE, F., ALI, Q. and MALIK, A., 2020. Genetic modification for salt and drought tolerance in plants through SODERF3. Biological and Clinical Sciences Research Journal, vol. 2020, no. 1, pp. e22.

ALI, Q. and MALIK, A., 2021. Genetic evaluation of legume species under heavy metal and biogas wastewater treatments. Biological and Clinical Sciences Research Journal, vol. 2021, no. 1, pp. e001-e001.

ASHIKARI, M., WU, J., YANO, M., SASAKI, T. and YOSHIMURA, A., 1999. Rice gibberellin-insensitive dwarf mutant gene Dwarf 1 encodes the $\alpha$-subunit of GTP-binding protein. Proceedings of the National Academy of Sciences of the United States of America, vol. 96, no. 18, pp. 10284-10289. http://dx.doi.org/10.1073/ pnas.96.18.10284. PMid:10468600.

ASPENSTRÖM, P., 2019. The intrinsic gdp/gtp exchange activities of Cdc42 and rac1 are critical determinants for their specific effects on mobilization of the actin filament system. Cells, vol. 8, no. 7, pp. 759. http://dx.doi.org/10.3390/cells8070759. PMid:31330900.

BALQEES, N., ALI, Q. and MALIK, A., 2020. Genetic evaluation for seedling traits of maize and wheat under biogas wastewater, sewage water and drought stress conditions. Biological and Clinical Sciences Research Journal, vol. 2020, no. 1, pp. e038-e038.

BASHIR, M., ALI, Q., RASHID, M. and MALIKA, A., 2020. Crispr/cas9 in genome editing: a nature gifted molecular tool. Biological and Clinical Sciences Research Journal, vol. 2020, no. 1, pp. e018-e018.

BAUERFEIND, R. and HUTTNER, W.B., 1993. Biogenesis of constitutive secretory vesicles, secretory granules and synaptic vesicles. Current Opinion in Cell Biology, vol. 5, no. 4, pp. 628-635. http:// dx.doi.org/10.1016/0955-0674(93)90132-A. PMid:8257604.

BAZOPOULOU, D. and TAVERNARAKIS, N., 2009. The NemaGENETAG initiative: large scale transposon insertion gene-tagging in Caenorhabditis elegans. Genetica, vol. 137, no. 1, pp. 39-46. http://dx.doi.org/10.1007/s10709-009-9361-3. PMid:19343510.

BHATT, A.M. and DEAN, C., 1992. Development of tagging systems in plants using heterologous transposons. Current Opinion in Biotechnology, vol. 3, no. 2, pp. 152-158. http://dx.doi. org/10.1016/0958-1669(92)90145-9.

BI, Y.M., KANT, S., CLARKE, J., GIDDA, S., MING, F., XU, J., ROCHON, A., SHELP, B.J., HAO, L., ZHAO, R., MULLEN, R.T., ZHU, T. and ROTHSTEIN, S.J., 2009. Increased nitrogen-use efficiency in transgenic rice plants over-expressing a nitrogen-responsive early nodulin gene identified from rice expression profiling. Plant, Cell \& Environment, vol. 32, no. 12, pp. 1749-1760. http:// dx.doi.org/10.1111/j.1365-3040.2009.02032.x. PMid:19682292.

BISCHOFF, F., MOLENDIJK, A., RAJENDRAKUMAR, C. and PALME, K., 1999. GTP-binding proteins in plants. Cellular and Molecular Life Sciences CMLS, vol. 55, no. 2, pp. 233-256. http://dx.doi. org/10.1007/s000180050287. PMid:10188584.

BISHOP, G.J., HARRISON, K. and JONES, J., 1996. The tomato Dwarf gene isolated by heterologous transposon tagging encodes the first member of a new cytochrome P450 family. The Plant Cell, vol. 8, no. 6, pp. 959-969. PMid:8672892.

BRITTON, R.A., CHEN, S.M., WALLIS, D., KOEUTH, T., POWELL, B.S., SHAFFER, L.G., LARGAESPADA, D., JENKINS, N.A., COPELAND, N.G., COURT, D.L. and LUPSKI, J.R., 2000. Isolation and preliminary characterization of the human and mouse homologues of the bacterial cell cycle gene era. Genomics, vol. 67, no. 1, pp.78-82. http://dx.doi.org/10.1006/geno.2000.6243.

CAMACHO, M., BURGOS, A. and CHAMBER-PÉREZ, M.A., 2003. Nitrogen fixation in transposon mutants from Bradyrhizobium japonicum USDA 110 impaired in nitrate reductase. Journal of 
plant physiology, vol. 160 , no. 4, pp. 377-386. http://dx.doi. org/10.1078/0176-1617-00647. PMid:12756917.

CAO, Y., YAN, Y., ZHANG, F., WANG, H.-D., GU, M., WU, X.N., SUN, S.B. and XU, G.H., 2014. Fine characterization of OsPHO2 knockout mutants reveals its key role in Pi utilization in rice. Journal of Plant Physiology, vol. 171, no. 3-4, pp. 340-348. http://dx.doi. org/10.1016/j.jplph.2013.07.010. PMid:24268791.

CHANDLEE, J.M., 1990. The utility of transposable elements as tools for the isolation of plant genes. Physiologia Plantarum, vol. 79, no. 1, pp. 105-115. http://dx.doi.org/10.1111/j.1399-3054.1990. tb05872.x.

CHAO, L.H. and AVRUCH, J., 2019. Cryo-EM insight into the structure of MTOR complex 1 and its interactions with Rheb and substrates. F1000 Research, vol. 8, pp. F1000. http://dx.doi. org/10.12688/f1000research.16109.1.

CHARNG, Y., LI, H., CHANG, H., LI, K., HSEU, T. and TU, J., 2004. Fusion of the transposase with a classical nuclear localization signal to increase the transposition efficiency of Ac transposon. Botanical Bulletin of Academia Sinica, vol. 45, pp. 267-274.

CHEN, J., YI, Q., CAO, Y., WEI, B., ZHENG, L., XIAO, Q., XIE, Y., GU, Y., LI, Y., HUANG, H., WANG, Y., HOU, X., LONG, T., ZHANG, J., LIU, H., LIU, Y., YU, G. and HUANG, Y., 2016. ZmbZIP91 regulates expression of starch synthesis-related genes by binding to ACTCAT elements in their promoters. Journal of Experimental Botany, vol. 67, no. 5, pp. 1327-1338. http://dx.doi.org/10.1093/ jxb/erv527. PMid:26689855.

CHEN, W., FENG, Y., CHEN, D. and WANDINGER-NESS, A., 1998. Rab11 is required for trans-golgi network-to-plasma membrane transport and a preferential target for GDP dissociation inhibitor. Molecular Biology of the Cell, vol. 9, no. 11, pp. 3241-3257. http:// dx.doi.org/10.1091/mbc.9.11.3241. PMid:9802909.

CHEN, Y., YANG, X., YUAN, S.K., LI, Y.F., ZHANG, A.-F., YAO, J. and GAO, T.-C., 2015. Effect of azoxystrobin and kresoxim-methyl on rice blast and rice grain yield in China. Annals of Applied Biology, vol. 166, no. 3, pp. 434-443. http://dx.doi.org/10.1111/aab.12202.

CHIN, H.G., CHOE, M.S., LEE, S.-H., PARK, S.H., PARK, S.H., KOO, J.C., KIM, N.Y., LEE, J.J., OH, B.G., YI, G.H., KIM, S.C., CHOI, H.C., CHO, M.J. and HAN, C., 1999. Molecular analysis of rice plants harboring an Ac/Ds transposable element-mediated gene trapping system. The Plant Journal, vol. 19, no. 5, pp. 615-623. http:// dx.doi.org/10.1046/j.1365-313X.1999.00561.x. PMid:10504583.

CHOPRA, S., BRENDEL, V., ZHANG, J., AXTELL, J.D. and PETERSON, T., 1999. Molecular characterization of a mutable pigmentation phenotype and isolation of the first active transposable element from Sorghum bicolor. Proceedings of the National Academy of Sciences of the United States of America, vol. 96, no. 26, pp. 15330-15335. http://dx.doi.org/10.1073/pnas.96.26.15330. PMid: 10611384.

CHUCK, G., ROBBINS, T., NIJJAR, C., RALSTON, E., COURTNEYGUTTERSON, N. and DOONER, H.K., 1993. Tagging and cloning of a petunia flower color gene with the maize transposable element Activator. The Plant Cell, vol. 5, no. 4, pp. 371-378. http://dx.doi.org/10.2307/3869718. PMid:12271068.

COURAGE-TEBBE, U., DÖRING, H.-P., FEDOROFF, N. and STARLINGER, P., 1983. The controlling element Ds at the Shrunken locus in Zea mays: structure of the unstable sh-m5933 allele and several revertants. Cell, vol. 34, no. 2, pp. 383-393. http://dx.doi. org/10.1016/0092-8674(83)90372-0. PMid:6311430.

CRACIUN, A., JACOBS, M. and VAUTERIN, M., 2000. Arabidopsis loss-of-function mutant in the lysine pathway points out complex regulation mechanisms. FEBS Letters, vol. 487, no. 2 , pp. 234-238. http://dx.doi.org/10.1016/S0014-5793(00)023036. PMid:11150516.
DIAS, M.V.S., BASSO JUNIOR, L.R. and COELHO, P.S., 2008. New transposons to generate GFP protein fusions in Candida albicans. Gene, vol. 417, no. 1-2, pp. 13-18. http://dx.doi.org/10.1016/j. gene.2008.03.005. PMid:18467040.

DING, W.J., YANG, Y., CHEN, Z.X., WANG, Y.Y., DONG, W.L., CEN, J.N., QI, X.F., JIANG, F. and CHEN, S.N., 2018. Methylation level of Rap1GAP and the clinical significance in MDS. Oncology letters, vol. 16, no. 9, pp. 7287-7294. https://doi.org/10.3892/ ol.2018.9503.

DOHLMAN, H.G., SONG, J., MA, D., COURCHESNE, W.E. and THORNER, J., 1996. Sst2, a negative regulator of pheromone signaling in the yeast Saccharomyces cerevisiae: expression, localization, and genetic interaction and physical association with Gpa1 (the G-protein alpha subunit). Molecular and Cellular Biology, vol. 16, no. 9, pp. 5194-5209. http://dx.doi.org/10.1128/MCB.16.9.5194. PMid:8756677.

DU, B., ZHANG, W., LIU, B., HU, J., WEI, Z., SHI, Z., HE, R., ZHU, L., CHEN, R., HAN, B. and HE, G., 2009. Identification and characterization of Bph14, a gene conferring resistance to brown planthopper in rice. Proceedings of the National Academy of Sciences of the United States of America, vol. 106, no. 52, pp. 22163-22168. http://dx.doi.org/10.1073/pnas.0912139106. PMid:20018701.

DU, Y., HU, X.-F., WU, X.-H., SHU, Y., JIANG, Y. and YAN, X.J., 2013. Affects of mining activities on Cd pollution to the paddy soils and rice grain in Hunan province, Central South China. Environmental Monitoring and Assessment, vol. 185, no. 12, pp. 9843-9856. http://dx.doi.org/10.1007/s10661-013-3296-y. PMid:23775460.

DUFRESNE, M., VAN DER LEE, T., BEN M'BAREK, S., XU, X., ZHANG, X., LIU, T., WAALWIJK, C., ZHANG, W., KEMA, G.H. and DABOUSSI, M.J., 2008. Transposon-tagging identifies novel pathogenicity genes in Fusarium graminearum. Fungal Genetics and Biology, vol. 45, no. 12, pp. 1552-1561. http://dx.doi.org/10.1016/j. fgb.2008.09.004. PMid:18926918.

EMMANUEL, E. and LEVY, A.A., 2002. Tomato mutants as tools for functional genomics. Current Opinion in Plant Biology, vol. 5, no. 2, pp. 112-117. http://dx.doi.org/10.1016/S1369-5266(02)002376. PMid:11856605.

ENOKI, H., IZAWA, T., KAWAHARA, M., KOMATSU, M., KOH, S., KYOZUKA, J. and SHIMAMOTO, K., 1999. Ac as a tool for the functional genomics of rice. The Plant Journal, vol. 19, no. 5, pp. 605-613. http://dx.doi.org/10.1046/j.1365-313X.1999.00549.x. PMid:10504582.

EOM, E.-M., CHO, J.-K., LIM, S.-O., BYUN, Y.-J. and LEE, D.-H., 2006. Molecular cloning and expression of a small GTP-binding protein of the Rop family from mung bean. Plant Science, vol. 171, no. 1, pp. 41-51. http://dx.doi.org/10.1016/j.plantsci.2006.02.011.

ETIENNE-MANNEVILLE, S. and HALL, A., 2002. Rho GTPases in cell biology. Nature, vol. 420, no. 6916, pp. 629-635. http://dx.doi. org/10.1038/nature01148. PMid:12478284.

FAROOQ, M., BASHIR, M., KHAN, M., IQBAL, B. and ALI, Q., 2021. Role of crispr to improve abiotic stress tolerance in crop plants. Biological and Clinical Sciences Research Journal, vol. 2021, no. 1, pp. e022-e022.

FENG, B., MANDAVA, C.S., GUO, Q., WANG, J., CAO, W., LI, N., ZHANG, Y., ZHANG, Y., WANG, Z., WU, J., SANYAL, S., LEI, J. and GAO, N., 2014. Structural and functional insights into the mode of action of a universally conserved Obg GTPase. PLoS Biology, vol. 12, no. 5, pp. e1001866. http://dx.doi.org/10.1371/journal. pbio.1001866. PMid:24844575.

FESCHOTTE, C., JIANG, N. and WESSLER, S.R., 2002. Plant transposable elements: where genetics meets genomics. Nature Reviews. 
Genetics, vol. 3, no. 5, pp. 329-341. http://dx.doi.org/10.1038/ nrg793. PMid:11988759.

FITZMAURICE, W.P., LEHMAN, L.J., NGUYEN, L.V., THOMPSON, W.F., WERNSMAN, E.A. and CONKLING, M.A., 1992. Development and characterization of a generalized gene tagging system for higher plants using an engineered maize transposon Ac. Plant Molecular Biology, vol. 20, no. 2, pp. 177-198. http://dx.doi. org/10.1007/BF00014487. PMid:1327269.

FU, F.-F. and XUE, H.W., 2010. Coexpression analysis identifies Rice Starch Regulator1, a rice AP2/EREBP family transcription factor, as a novel rice starch biosynthesis regulator. Plant Physiology, vol. 154, no. 2, pp. 927-938. http://dx.doi.org/10.1104/pp.110.159517. PMid:20713616.

FUJINO, K., SEKIGUCHI, H. and KIGUCHI, T., 2005. Identification of an active transposon in intact rice plants. Molecular Genetics and Genomics, vol.273, no. 2, pp. 150-157. http://dx.doi.org/10.1007/ s00438-005-1131-z. PMid:15803319.

FUJINO, K., SEKIGUCHI, H., MATSUDA, Y., SUGIMOTO, K., ONO, K. and YANO, M., 2008. Molecular identification of a major quantitative trait locus, qLTG3-1, controlling low-temperature germinability in rice. Proceedings of the National Academy of Sciences of the United States of America, vol. 105, no. 34, pp. 12623-12628. http://dx.doi.org/10.1073/pnas.0805303105. PMid:18719107.

FUJISAWA, Y., KATO, H. and IWASAKI, Y., 2001. Structure and function of heterotrimeric G proteins in plants. Plant $\mathcal{E}$ Cell Physiology, vol. 42, no. 8, pp. 789-794. http://dx.doi.org/10.1093/pcp/ pce111. PMid:11522903.

GALE, M.D. and DEVOS, K.M., 1998. Comparative genetics in the grasses. Proceedings of the National Academy of Sciences of the United States of America, vol. 95, no. 5, pp. 1971-1974. http:// dx.doi.org/10.1073/pnas.95.5.1971. PMid:9482816.

GHAFOOR, M., ALI, Q. and MALIK, A., 2020. Effects of salicylic acid priming for salt stress tolerance in wheat. Biological and Clinical Sciences Research Journal, vol. 2020, no. 1, pp. e024-e024.

GIROUX, M.J., CLANCY, M., BAIER, J., INGHAM, L., MCCARTY, D. and HANNAH, L.C., 1994. De novo synthesis of an intron by the maize transposable element Dissociation. Proceedings of the National Academy of Sciences of the United States of America, vol. 91, no. 25, pp. 12150-12154. http://dx.doi.org/10.1073/ pnas.91.25.12150. PMid:7991598.

GOFF, S.A., 1999. Rice as a model for cereal genomics. Current Opinion in Plant Biology, vol. 2, no. 2, pp. 86-89. http://dx.doi. org/10.1016/S1369-5266(99)80018-1. PMid:10322198.

GOFF, S.A., RICKE, D., LAN, T.-H., PRESTING, G., WANG, R., DUNN, M., GLAZEBROOK, J., SESSIONS, A., OELLER, P., VARMA, H., HADLEY, D., HUTCHISON, D., MARTIN, C., KATAGIRI, F., LANGE, B.M., MOUGHAMER, T., XIA, Y., BUDWORTH, P., ZHONG, J., MIGUEL, T., PASZKOWSKI, U., ZHANG, S., COLBERT, M., SUN, W.L., CHEN, L., COOPER, B., PARK, S., WOOD, T.C., MAO, L., QUAIL, P., WING, R., DEAN, R., YU, Y., ZHARKIKH, A., SHEN, R., SAHASRABUDHE, S., THOMAS, A., CANNINGS, R., GUTIN, A., PRUSS, D., REID, J., TAVTIGIAN, S., MITCHELL, J., ELDREDGE, G., SCHOLL, T., MILLER, R.M., BHATNAGAR, S., ADEY, N., RUBANO, T., TUSNEEM, N., ROBINSON, R., FELDHAUS, J., MACALMA, T., OLIPHANT, A. and BRIGGS, S., 2002. A draft sequence of the rice genome (Oryza sativa L. ssp. japonica). Science, vol. 296, no. 5565, pp. 92-100. http://dx.doi.org/10.1126/science.1068275. PMid:11935018.

GONZÁLEZ-GONZÁLEZ, R., GUERRA-MORENO, J.A., CRISTÓBALMONDRAGÓN, G.R., ROMERO, V., PEÑA-GÓMEZ, S.G., MONTEROMORÁN, G.M., LARA-GONZÁLEZ, S., HERNÁNDEZ-ARANA, A., FERNÁNDEZ-VELASCO, D.A., CALERA, M.R. and SÁNCHEZ-OLEA, R., 2017. Human Gpn1 purified from bacteria binds guanine nucleotides and hydrolyzes GTP as a protein dimer stabilized by its C-terminal tail. Protein Expression and Purification, vol. 132, pp. 85-96. http://dx.doi.org/10.1016/j.pep.2017.01.009. PMid:28153773.

GOUVEIA, N., GHERARDI, D. and ARAGÃO, L., 2019. The role of the Amazon river plume on the intensification of the hydrological cycle. Geophysical Research Letters, vol. 46, no. 21, pp. 1222112229. http://dx.doi.org/10.1029/2019GL084302.

GRANDBASTIEN, M.-A., 1998. Activation of plant retrotransposons under stress conditions. Trends in Plant Science, vol. 3, no. 5, pp. 181-187. http://dx.doi.org/10.1016/S1360-1385(98)01232-1.

GRECO, R., OUWERKERK, P.B., SALLAUD, C., KOHLI, A., COLOMBO, L., PUIGDOMÈNECH, P., GUIDERDONI, E., CHRISTOU, P., HOGE, J.H. and PEREIRA, A., 2001. Transposon insertional mutagenesis in rice. Plant Physiology, vol. 125, no. 3, pp. 1175-1177. http:// dx.doi.org/10.1104/pp.125.3.1175. PMid:11244097.

HALLAM, A., 1990. The cellular functions of small GTP-binding proteins. Science, vol. 249, no. 4969, pp. 635-640. http://dx.doi. org/10.1126/science.2116664. PMid:2116664.

HAMER, L., DEZWAAN, T.M., MONTENEGRO-CHAMORRO, M.V., FRANK, S.A. and HAMER, J.E., 2001. Recent advances in largescale transposon mutagenesis. Current Opinion in Chemical Biology, vol. 5, no. 1, pp. 67-73. http://dx.doi.org/10.1016/ S1367-5931(00)00162-9. PMid:11166651.

HARRIS, S.B., 2002. Virtual rice: japan sets up the Rice Simulator Project to create an in silico rice plant. EMBO Reports, vol. 3, no. 6, pp. 511-513. http://dx.doi.org/10.1093/embo-reports/ kvf125. PMid:12052769.

HASEEB, A., NAWAZ, A., RAO, M., ALI, Q., and MALIK, A., 2020. Genetic variability and association among seedling traits of Zea mays under drought stress conditions. Biological and Clinical Sciences Research Journal, vol. 2020, no. 1, pp. e020.

HATTORI, Y., NAGAI, K., FURUKAWA, S., SONG, X.-J., KAWANO, R., SAKAKIBARA, H., WU, J., MATSUMOTO, T., YOSHIMURA, A., KITANO, H., MATSUOKA, M., MORI, H. and ASHIKARI, M., 2009. The ethylene response factors SNORKEL1 and SNORKEL2 allow rice to adapt to deep water. Nature, vol. 460, no. 7258, pp. 10261030. http://dx.doi.org/10.1038/nature08258. PMid:19693083.

HE, P., LI, S., QIAN, Q., MA, Y., LI, J.Z., WANG, W.M., CHEN, Y. and ZHU, L.H., 1999. Genetic analysis of rice grain quality. Theoretical and Applied Genetics, vol. 98, no. 3-4, pp. 502-508. http://dx.doi. org/10.1007/s001220051098.

HEPLER, J.R. and GILMAN, A.G., 1992. G proteins. Trends in Biochemical Sciences, vol. 17, no. 10, pp. 383-387. http://dx.doi. org/10.1016/0968-0004(92)90005-T. PMid:1455506.

HIROCHIKA, H., 1997. Retrotransposons of rice: their regulation and use for genome analysis. Plant Molecular Biology, vol. 35, pp. 231-240.

HIROCHIKA, H., GUIDERDONI, E., AN, G., HSING, Y.I., EUN, M.Y., HAN, C.D., UPADHYAYA, N., RAMACHANDRAN, S., ZHANG, Q., PEREIRA, A., SUNDARESAN, V. and LEUNG, H., 2004. Rice mutant resources for gene discovery. Plant Molecular Biology, vol. 54, no. 3, pp. 325334. http://dx.doi.org/10.1023/B:PLAN.0000036368.74758.66. PMid:15284490.

HIROCHIKA, H., MIYAO, A., YAMAZAKI, M., TAKEDA, S., ABE, K., HIROCHIKA, R., AGRAWAL, G.K., WATANABE, T., SUGIMOTO, K., SASAKI, T., MURATA, K. and TANAKA, K. Retrotransposons of rice as a tool for the functional analysis of genes. In: G.S. KLUSH, D.S. BRAR and B. HARDY, eds. Rice genetics IV. USA: Science Publisher, Inc., 2001, pp. 279-292.

HIROCHIKA, H., SUGIMOTO, K., OTSUKI, Y., TSUGAWA, H. and KANDA, M., 1996. Retrotransposons of rice involved in mutations induced by tissue culture. Proceedings of the National Academy of Sciences 
of the United States of America, vol. 93, no. 15, pp. 7783-7788. http://dx.doi.org/10.1073/pnas.93.15.7783. PMid:8755553.

HOMMA, Y., HIRAGI, S. and FUKUDA, M., 2021. Rab family of small GTPases: an updated view on their regulation and functions. The FEBS Journal, vol. 288, no. 1, pp. 36-55. http://dx.doi.org/10.1111/ febs.15453. PMid:32542850.

HORIUCHI, H., LIPPÉ, R., MCBRIDE, H.M., RUBINO, M., WOODMAN, P., STENMARK, H., RYBIN, V., WILM, M., ASHMAN, K., MANN, M. and ZERIAL, M., 1997. A novel Rab5 GDP/GTP exchange factor complexed to Rabaptin-5 links nucleotide exchange to effector recruitment and function. Cell, vol. 90, no. 6, pp. 1149-1159. http://dx.doi.org/10.1016/S0092-8674(00)803803. PMid:9323142.

HSING, Y.-I., CHERN, C.-G., FAN, M.-J., LU, P.-C., CHEN, K.T., LO, S.F., SUN, P.K., HO, S.L., LEE, K.W., WANG, Y.C., HUANG, W.L., KO, S.S., CHEN, S., CHEN, J.L., CHUNG, C.I., LIN, Y.C., HOUR, A.L., WANG, Y.W., CHANG, Y.C., TSAI, M.W., LIN, Y.S., CHEN, Y.C., YEN, H.M., LI, C.P., WEY, C.K., TSENG, C.S., LAI, M.H., HUANG, S.C., CHEN, L.J. and YU, S.M., 2007. A rice gene activation/knockout mutant resource for high throughput functional genomics. Plant Molecular Biology, vol. 63, no. 3, pp. 351-364. http://dx.doi. org/10.1007/s11103-006-9093-Z. PMid:17120135.

HUANG, J., ZHANG, K., SHEN, Y., HUANG, Z., LI, M., TANG, D., GU, M. and CHENG, Z., 2009. Identification of a high frequency transposon induced by tissue culture, nDaiz, a member of the hAT family in rice. Genomics, vol. 93, no. 3, pp. 274-281. http://dx.doi.org/10.1016/j.ygeno.2008.11.007. PMid:19071208.

HUA-YING, M., WEN-JU, W., WEI-HUA, S., YA-CHUN, S., FENG, L., CONG-NA, L., LING, W., XU, Z., LI-PING, X. and YOU-XIONG, Q. 2019. Genome-wide identification, phylogeny, and expression analysis of Sec14-like PITP gene family in sugarcane. Plant Cell Reports, vol. 38, no. 5, pp. 637-655. http://dx.doi.org/10.1007/ s00299-019-02394-1. PMid:30747272.

IPEK, A. and SIMON, P., 2002. Developing an Ac/Ds based twoelement transposon tagging system in carrot. In Plant $\mathcal{E}$ Animal Genome XMeeting, 12-16 January, 2002. Madison, WI, USA. pp. 4.

IQBAL, S., ALI, Q., and MALIK, A., 2021. Effects of seed priming with salicylic acid on zea mays seedlings grown under salt stress conditions. Biological and Clinical Sciences Research Journal, vol. 2021, no. 1, pp. e016.

IQRA, L., RASHID, M., ALI, Q., LATIF, I., and MALIK, A., 2020. Evaluation of genetic variability for salt tolerance in wheat. Biological and Clinical Sciences Research Journal, vol. 2020, no. 1, pp. e016.

ISHIKAWA, S., MAEKAWA, M., ARITE, T., ONISHI, K., TAKAMURE, I. and KYOZUKA, J., 2005. Suppression of tiller bud activity in tillering dwarf mutants of rice. Plant E Cell Physiology, vol. 46, no. 1, pp. 79-86. http://dx.doi.org/10.1093/pcp/pci022. PMid: 15659436.

IZAWA, T., OHNISHI, T., NAKANO, T., ISHIDA, N., ENOKI, H., HASHIMOTO, H., ITOH, K., TERADA, R., WU, C., MIYAZAKI, C., ENDO, T., IIDA, S., \& SHIMAMOTO, K., 1997. Transposon tagging in rice. Plant Molecular Biology, pp. 219-229.

JAMES JUNIOR, D.W., LIM, E., KELLER, J., PLOOY, I., RALSTON, E. and DOONER, H.K., 1995. Directed tagging of the Arabidopsis Fatty Acid Elongation1 (FAE1) gene with the maize transposon activator. The Plant Cell, vol. 7, no. 3, pp. 309-319. PMid:7734965.

JAVIED, M., ASHFAQ N., HAIDER, M., FATIMA, F., ALI, Q., ALI, A., and MALIK, A., 2021. Agrobacterium-mediated transformation of cotton (Gossypium hirsutum L.) using dmo gene for enhanced tolerance against dicamba pesticide. Biological and Clinical Sciences Research Journal, vol. 2021, no. 1, pp. e009.

JEON, J. and AN, G., 2001. Gene tagging in rice: a high throughput system for functional genomics. Plant Science, vol. 161, no. 2, pp. 211-219. http://dx.doi.org/10.1016/S0168-9452(01)004149. PMid:11448751.

JIANG, N., BAO, Z., ZHANG, X., HIROCHIKA, H., EDDY, S.R., MCCOUCH, S.R. and WESSLER, S.R., 2003. An active DNA transposon family in rice. Nature, vol. 421, no. 6919, pp. 163-167. http://dx.doi. org/10.1038/nature01214. PMid:12520302.

JIANG, N., FESCHOTTE, C., ZHANG, X. and WESSLER, S.R., 2004. Using rice to understand the origin and amplification of miniature inverted repeat transposable elements (MITEs). Current Opinion in Plant Biology, vol. 7, no. 2, pp. 115-119. http://dx.doi. org/10.1016/j.pbi.2004.01.004. PMid:15003209.

JIANG, S.-Y. and RAMACHANDRAN, S., 2010. Natural and artificial mutants as valuable resources for functional genomics and molecular breeding. International Journal of Biological Sciences, vol. 6, no. 3, pp. 228-251. http://dx.doi.org/10.7150/ijbs.6.228. PMid:20440406.

JONES, A.M. and ASSMANN, S.M., 2004. the latest model system for G-protein research. EMBO Reports, vol. 5, no. 6, pp. 572-578. http://dx.doi.org/10.1038/sj.embor.7400174. PMid:15170476.

JONES, D.A., THOMAS, C.M., HAMMOND-KOSACK, K.E., BALINTKURTI, P.J. and JONES, J.D., 1994. Isolation of the tomato Cf-9 gene for resistance to Cladosporium fulvum by transposon tagging. Science, vol. 266, no. 5186, pp. 789-793. http://dx.doi. org/10.1126/science.7973631. PMid:7973631.

KAEPPLER, S. M., KAEPPLER, H.F. and RHEE, Y., 2000. Epigenetic aspects of somaclonal variation in plants. Plant Gene Silencing, 59-68.

KAIBUCHI, K., KURODA, S. and AMANO, M., 1999. Regulation of the cytoskeleton and cell adhesion by the Rho family GTPases in mammalian cells. Annual Review of Biochemistry, vol. 68, no. 1, pp. 459-486. http://dx.doi.org/10.1146/annurev.biochem.68.1.459. PMid:10872457.

KANEKO, M., INUKAI, Y., UEGUCHI-TANAKA, M., ITOH, H., IZAWA, T., KOBAYASHI, Y., HATTORI, T., MIYAO, A., HIROCHIKA, H., ASHIKARI, M. and MATSUOKA, M., 2004. Loss-of-function mutations of the rice GAMYB gene impair $\alpha$-amylase expression in aleurone and flower development. The Plant Cell, vol. 16, no. 1, pp. 33-44. http://dx.doi.org/10.1105/tpc.017327. PMid:14688295.

KAZIRO, Y., ITOH, H., KOZASA, T., NAKAFUKU, M. and SATOH, T., 1991. Structure and function of signal-transducing GTP-binding proteins. Annual Review of Biochemistry, vol. 60, no. 1, pp. 349400. http://dx.doi.org/10.1146/annurev.bi.60.070191.002025. PMid:1909108.

KELLY, M.N. and IRVING, H.R., 2003. Nod factors activate both heterotrimeric and monomeric $\mathrm{G}$-proteins in Vigna unguiculata (L.) Walp. Planta, vol. 216, no. 4, pp. 674-685. http://dx.doi. org/10.1007/s00425-002-0900-8. PMid:12569410.

KEMPIN, S.A., LILJEGREN, S.J., BLOCK, L.M., ROUNSLEY, S.D., YANOFSKY, M.F. and LAM, E., 1997. Targeted disruption in Arabidopsis. Nature, vol. 389, no. 6653, pp. 802-803. http:// dx.doi.org/10.1038/39770. PMid:9349810.

KHUSH, G.S., 1997. Origin, dispersal, cultivation and variation of rice. Plant Molecular Biology, vol. 35, no. 1, pp. 25-34. http:// dx.doi.org/10.1023/A:1005810616885. PMid:9291957.

KIKUCHI, K., TERAUCHI, K., WADA, M. and HIRANO, H.-Y., 2003. The plant MITE mPing is mobilized in anther culture. Nature, vol. 421, no. 6919, pp. 167-170. http://dx.doi.org/10.1038/ nature01218. PMid:12520303.

KIM, H.-Y., SCHIEFELBEIN, J.W., RABOY, V., FURTEK, D.B. and NELSON JUNIOR, O.E., 1987. RNA splicing permits expression of a maize gene with a defective Suppressor-mutator transposable element insertion in an exon. Proceedings of the National Academy of 
Sciences of the United States of America, vol. 84, no. 16, pp. 58635867. http://dx.doi.org/10.1073/pnas.84.16.5863. PMid:3039512.

KIRAL, F.R., KOHRS, F.E., JIN, E.J. and HIESINGER, P.R., 2018. Rab GTPases and membrane trafficking in neurodegeneration. Current Biology, vol. 28, no. 8, pp. R471-R486. http://dx.doi. org/10.1016/j.cub.2018.02.010. PMid:29689231.

KISHI, T. and YAMAO, F., 1998. An essential function of Grr1 for the degradation of $\mathrm{Cln} 2$ is to act as a binding core that links Cln2 to Skp1. Journal of Cell Science, vol. 111, no. 24, pp. 36553661. http://dx.doi.org/10.1242/jcs.111.24.3655. PMid:9819356.

KIYOSUE, T. and SHINOZAKI, K., 1995. Cloning of a carrot cDNA for a member of the family of ADP-ribosylation factors (ARFs) and characterization of the binding of nucleotides by its product after expression in E. coli. Plant \& Cell Physiology, vol. 36, no. 5, pp. 849-856. http://dx.doi.org/10.1093/oxfordjournals.pcp. a078830. PMid:7551586.

KLOPFFLEISCH, K., PHAN, N., AUGUSTIN, K., BAYNE, R.S., BOOKER, K.S., BOTELLA, J.R., CARPITA, N.C., CARR, T., CHEN, J.G., COOKE, T.R., FRICK-CHENG, A., FRIEDMAN, E.J., FULK, B., HAHN, M.G., JIANG, K., JORDA, L., KRUPPE, L., LIU, C., LOREK, J., MCCANN, M.C., MOLINA, A., MORIYAMA, E.N., MUKHTAR, M.S., MUDGIL, Y., PATTATHIL, S., SCHWARZ, J., SETA, S., TAN, M., TEMP, U., TRUSOV, Y., URANO, D., WELTER, B., YANG, J., PANSTRUGA, R., UHRIG, J.F. and JONES, A.M., 2011. Arabidopsis G-protein interactome reveals connections to cell wall carbohydrates and morphogenesis. Molecular Systems Biology, vol. 7, no. 1, pp. 532. http://dx.doi.org/10.1038/msb.2011.66. PMid:21952135.

KOCH, B., TUCEY, T.M., LO, T.L., NOVAKOVIC, S., BOAG, P. and TRAVEN, A., 2017. The mitochondrial GTPase Gem1 contributes to the cell wall stress response and invasive growth of Candida albicans. Frontiers in Microbiology, vol. 8, pp. 2555. http://dx.doi. org/10.3389/fmicb.2017.02555. PMid:29326680.

KOLESNIK, T., SZEVERENYI, I., BACHMANN, D., KUMAR, C.S., JIANG, S., RAMAMOORTHY, R., CAI, M., MA, Z.G., SUNDARESAN, V. and RAMACHANDRAN, S., 2004. Establishing an efficient Ac/ Ds tagging system in rice: large-scale analysis of Ds flanking sequences. The Plant Journal, vol. 37, no. 2, pp. 301-314. http:// dx.doi.org/10.1046/j.1365-313X.2003.01948.x. PMid:14690513.

KOMATSU, M., SHIMAMOTO, K. and KYOZUKA, J., 2003. Twostep regulation and continuous retrotransposition of the rice LINE-type retrotransposon Karma. The Plant Cell, vol. 15 , no. 8, pp. 1934-1944. http://dx.doi.org/10.1105/tpc.011809. PMid:12897263.

KONCZ, C., MARTINI, N., MAYERHOFER, R., KONCZ-KALMAN, Z., KÖRBER, H., REDEI, G.P. and SCHELL, J., 1989. High-frequency T-DNA-mediated gene tagging in plants. Proceedings of the National Academy of Sciences of the United States of America, vol. 86, no. 21, pp. 8467-8471. http://dx.doi.org/10.1073/ pnas.86.21.8467. PMid:2554318.

KOONIN, E. and GALPERIN, M.Y., 2002. Sequence-evolution-function: computational approaches in comparative genomics. Boston, MA: Kluwer Academic.

KRASENSKY, J. and JONAK, C., 2012. salt, and temperature stressinduced metabolic rearrangements and regulatory networks. Journal of Experimental Botany, vol. 63, no. 4, pp. 1593-1608. http://dx.doi.org/10.1093/jxb/err460. PMid:22291134.

KUMAR, A. and HIROCHIKA, H., 2001. Applications of retrotransposons as genetic tools in plant biology. Trends in Plant Science, vol. 6, no. 3, pp. 127-134. http://dx.doi.org/10.1016/S1360-1385(00)018604. PMid:11239612.

KUMAR, S., MISHRA, S., and GOURINATH, S., 2020. Structural and functional diversity of Entamoeba histolytica calcium-binding proteins. Biophysical Reviews, vol. 12, No. 6, pp. 1331-41.
KUNZE, R. and WEIL, C.F., 2002. The hAT and CACTA superfamilies of plant transposons. In: L.N. CRAIG, R. CRAIGIE, M. GELLERT and A.M. LAMBOWITZ, eds. Mobile DNA II. Washington: American Society of Microbiology, pp. 565-610.

KUROMORI, T., TAKAHASHI, S., KONDOU, Y., SHINOZAKI, K. and MATSUI, M., 2009. Phenome analysis in plant species using loss-of-function and gain-of-function mutants. Plant \&' Cell Physiology, vol. 50, no. 7, pp. 1215-1231. http://dx.doi. org/10.1093/pcp/pcp078. PMid:19502383.

LARKIN, P.J. and SCOWCROFT, W.R., 1981. Somaclonal variation - a novel source of variability from cell cultures for plant improvement. Theoretical and Applied Genetics, vol. 60, no. 4, pp. 197-214. http://dx.doi.org/10.1007/BF02342540. PMid:24276737.

LEIPE, D.D., KOONIN, E.V. and ARAVIND, L., 2003. Evolution and classification of P-loop kinases and related proteins. Journal of Molecular Biology, vol. 333, no. 4, pp. 781-815. http://dx.doi. org/10.1016/j.jmb.2003.08.040. PMid:14568537.

LEIPE, D.D., WOLF, Y.I., KOONIN, E.V. and ARAVIND, L., 2002. Classification and evolution of P-loop GTPases and related ATPases. Journal of Molecular Biology, vol. 317, no. 1, pp. 41-72. http://dx.doi.org/10.1006/jmbi.2001.5378. PMid:11916378.

LI, Y.-F., ZHAO, J., LI, Y., LI, H., ZHANG, J., LI, B., GAO, Y., CHEN, C., LUO, M., HUANG, R. and LI, J., 2015. The concentration of selenium matters: a field study on mercury accumulation in rice by selenite treatment in qingzhen, Guizhou, China. Plant and Soil, vol. 391, no. 1, pp. 195-205. http://dx.doi.org/10.1007/ s11104-015-2418-4.

LIN, X., LONG, L., SHAN, X., ZHANG, S., SHEN, S. and LIU, B., 2006. In planta mobilization of mPing and its putative autonomous element Pong in rice by hydrostatic pressurization. Journal of Experimental Botany, vol. 57, no. 10, pp. 2313-2323. http:// dx.doi.org/10.1093/jxb/erj203. PMid:16818484.

LIU, D., ZHANG, S., FAUQUET, C. and CRAWFORD, N., 1999. The Arabidopsis transposon Tag1 is active in rice, undergoing germinal transposition and restricted, late somatic excision. Molecular and General Genetics MGG, vol. 262, no. 3, pp. 413-420. http://dx.doi.org/10.1007/s004380051100. PMid:10589827.

LO, S.F., FAN, M.J., HSING, Y.I., CHEN, L.J., CHEN, S., WEN, I.C., LIU, Y.L., CHEN, K.T., JIANG, M.J., LIN, M.K., RAO, M.Y., YU, L.C., HO, T.H. and YU, S.M., 2016. Genetic resources offer efficient tools for rice functional genomics research. Plant, Cell \& Environment, vol. 39, no. 5, pp. 998-1013. http://dx.doi.org/10.1111/pce.12632. PMid:26301381.

LUCK, J.E., LAWRENCE, G.J., FINNEGAN, E.J., JONES, D.A. and ELLIS, J.G., 1998. A flax transposon identified in two spontaneous mutant alleles of the L6 rust resistance gene. The Plant Journal, vol. 16, no. 3, pp. 365-369. http://dx.doi.org/10.1046/j.1365313x.1998.00306.x. PMid:9881156.

LUO, D., COEN, E.S., DOYLE, S. and CARPENTER, R., 1991. Pigmentation mutants produced by transposon mutagenesis in Antirrhinum majus. The Plant Journal, vol. 1, no. 1, pp. 59-69. http://dx.doi. org/10.1111/j.1365-313X.1991.00059.x. PMid:1668965.

MA, H., 1994. GTP-binding proteins in plants: new members of an old family. Plant Molecular Biology, vol. 26, no. 5, pp. 16111636. http://dx.doi.org/10.1007/BF00016493. PMid:7858207.

MARTIENSSEN, R.A., 1998. Functional genomics: probing plant gene function and expression with transposons. Proceedings of the National Academy of Sciences of the United States of America, vol. 95, no. 5, pp. 2021-2026. http://dx.doi.org/10.1073/ pnas.95.5.2021. PMid:9482828.

MASOOD, M., AHSAN, M., SADAQAT, H., and AWAN, F., 2020. Screening of maize (Zea mays L.) inbred lines under water 
deficit conditions. Biological and Clinical Sciences Research Journal, vol. 2020, no. 1, pp. e007-e007.

MASUMOTO, C., MIYAZAWA, S.-I., OHKAWA, H., FUKUDA, T., TANIGUCHI, Y., MURAYAMA, S., KUSANO, M., SAITO, K., FUKAYAMA, H. and MIYAO, M., 2010. Phosphoenolpyruvate carboxylase intrinsically located in the chloroplast of rice plays a crucial role in ammonium assimilation. Proceedings of the National Academy of Sciences of the United States of America, vol. 107, no. 11, pp. 5226-5231. http://dx.doi.org/10.1073/ pnas.0913127107. PMid:20194759.

MATHIEU, M., WINTERS, E.K., KONG, F., WAN, J., WANG, S., ECKERT, H., LUTH, D., PAZ, M., DONOVAN, C., ZHANG, Z., SOMERS, D., WANG, K., NGUYEN, H., SHOEMAKER, R.C., STACEY, G. and CLEMENTE, T., 2009. Establishment of a soybean (Glycine max Merr. L) transposon-based mutagenesis repository. Planta, vol. 229, no. 2, pp. 279-289. http://dx.doi.org/10.1007/s00425-0080827-9. PMid:18855007.

MAY, B.P. and MARTIENSSEN, R.A., 2003. Transposon mutagenesis in the study of plant development. Critical Reviews in Plant Sciences, vol. 22, no. 1, pp. 1-35. http://dx.doi.org/10.1080/713610849.

MAZIER, M., BOTTON, E., FLAMAIN, F., BOUCHET, J.-P., COURTIAL, B., CHUPEAU, M.C., CHUPEAU, Y., MAISONNEUVE, B. and LUCAS, H., 2007. Successful gene tagging in lettuce using the Tnt1 retrotransposon from tobacco. Plant Physiology, vol. 144 no. 1, pp. 18-31. http://dx.doi.org/10.1104/pp.106.090365. PMid: 17351058 .

MCCARTY, D.R., CARSON, C.B., LAZAR, M. and SIMONDS, S.C., 1989. AND S. C. SIMONDS Transposable element-induced mutations of the viviparous-1 gene in maize. Developmental Genetics, vol. 10 , no. 6, pp. 473-481. http://dx.doi.org/10.1002/dvg.1020100608.

MCCLINTOCK, B., 1951 Chromosome organization and genic expression. Cold Spring Harbor Symposia on Quantitative Biology, vol. 16, pp. 13-47. http://dx.doi.org/10.1101/sqb.1951.016.01.004. PMid: 14942727

MIYAO, A., IWASAKI, Y., KITANO, H., ITOH, J.-I., MAEKAWA, M., MURATA, K., YATOU, O., NAGATO, Y. and HIROCHIKA, H., 2007. A large-scale collection of phenotypic data describing an insertional mutant population to facilitate functional analysis of rice genes. Plant Molecular Biology, vol. 63, no. 5, pp. 625-635. http://dx.doi.org/10.1007/s11103-006-9118-7. PMid:17180734.

MIYAO, A., TANAKA, K., MURATA, K., SAWAKI, H., TAKEDA, S., ABE, K., SHINOZUKA, Y., ONOSATO, K. and HIROCHIKA, H., 2003. Target site specificity of the Tos17 retrotransposon shows a preference for insertion within genes and against insertion in retrotransposon-rich regions of the genome. The Plant Cell, vol. 15, no. 8, pp. 1771-1780. http://dx.doi.org/10.1105/tpc.012559. PMid:12897251.

MIZOI, J., SHINOZAKI, K. and YAMAGUCHI-SHINOZAKI, K., 2012. AP2/ERF family transcription factors in plant abiotic stress responses. Biochimica et Biophysica Acta (BBA)- Gene Regulatory Mechanisms, vol. 1819, no. 2, pp. 86-96.

MOON, S., JUNG, K.-H., LEE, D.-E., JIANG, W.-Z., KOH, H.J., HEU, M.H., LEE, D.S., SUH, H.S. and AN, G., 2006. Identification of active transposon dTok, a member of the hAT family, in rice. Plant \& Cell Physiology, vol. 47, no. 11, pp. 1473-1483. http:// dx.doi.org/10.1093/pcp/pcl012. PMid:16990289.

MÜLLER, M.P. and GOODY, R.S., 2018. Molecular control of Rab activity by GEFs, GAPs and GDI. Small GTPases, vol. 9, no. 1-2, pp. 5-21. http://dx.doi.org/10.1080/21541248.2016.1276999. PMid:28055292.

MUQADAS, S., ALI, Q. and MALIK, A., 2020. Genetic association among seedling traits of Zea mays under multiple stresses of salts, heavy metals and drought. Biological and Clinical Sciences Research Journal, pp. e026.

MURAI, N., LI, Z., KAWAGOE, Y. and HAYASHIMOTO, A., 1991. Transposition of the maize activator element in transgenic rice plants. Nucleic Acids Research, vol. 19, no. 3, pp. 617-622. http:// dx.doi.org/10.1093/nar/19.3.617. PMid:1849265.

NAITO, K., ZHANG, F., TSUKIYAMA, T., SAITO, H., HANCOCK, C.N., RICHARDSON, A.O., OKUMOTO, Y., TANISAKA, T. and WESSLER, S.R., 2009. Unexpected consequences of a sudden and massive transposon amplification on rice gene expression. Nature, vol. 461, no. 7267, pp. 1130-1134. http://dx.doi.org/10.1038/ nature08479. PMid:19847266.

NAKAGAWA, Y., MACHIDA, C., MACHIDA, Y. and TORIYAMA, K., 2000. Frequency and pattern of transposition of the maize transposable element Ds in transgenic rice plants. Plant \& Cell Physiology, vol. 41, no. 6, pp. 733-742. http://dx.doi.org/10.1093/ pcp/41.6.733. PMid:10945343.

NAKAZAKI, T., OKUMOTO, Y., HORIBATA, A., YAMAHIRA, S., TERAISHI, M., NISHIDA, H., INOUE, H. and TANISAKA, T., 2003. Mobilization of a transposon in the rice genome. Nature, vol. 421, no. 6919, pp. 170-172. http://dx.doi.org/10.1038/nature01219. PMid:12520304.

NAWAZ, A., HASEEB, A., MALIK, H., ALI, Q., and MALIK, A., 2020. Genetic association among morphological traits of Zea mays seedlings under salt stress. Biological and Clinical Sciences Research Journal, pp. e21.

NEUVÉGLISE, C., NICAUDA, J.M., ROSS-MACDONALD, P. and GAILLARDIN, C., 1998. A shuttle mutagenesis system for tagging genes in the yeast Yarrowia lipolytica. Gene, vol. 213, no. 1-2, pp. 37-46. http://dx.doi.org/10.1016/S0378-1119(98)00205-4. PMid:9630501.

NEWMAN, A.M., LIU, C.L., GREEN, M.R., GENTLES, A.J., FENG, W., XU, Y., HOANG, C.D., DIEHN, M. and ALIZADEH, A.A., 2015. Robust enumeration of cell subsets from tissue expression profiles. Nature Methods, vol. 12, no. 5, pp. 453-457. http:// dx.doi.org/10.1038/nmeth.3337. PMid:25822800.

NICOL, L., CROCE, R., VAN GRONDELLE, R., VAN AMERONGEN, H., and VAN STOKKUM, I. Light harvesting in higher plants and green algae. In: R. CROCE, R. VAN GRONDELLE, H. VAN AMERONGEN and I. VAN STOKKUM, eds. Light harvesting in photosynthesis. Boca Raton: CRC Press, 2018, pp. 59-76.

NISHIYAMA, T., SAKAYAMA, H., DE VRIES, J., BUSCHMANN, H., SAINTMARCOUX, D., ULLRICH, K.K., HAAS, F.B., VANDERSTRAETEN, L., BECKER, D., LANG, D., VOSOLSOBĚ, S., ROMBAUTS, S., WILHELMSSON, P.K.I., JANITZA, P., KERN, R., HEYL, A., RÜMPLER, F., VILLALOBOS, L.I.A.C., CLAY, J.M., SKOKAN, R., TOYODA, A., SUZUKI, Y., KAGOSHIMA, H., SCHIJLEN, E., TAJESHWAR, N., CATARINO, B., HETHERINGTON, A.J., SALTYKOVA, A., BONNOT, C., BREUNINGER, H., SYMEONIDI, A., RADHAKRISHNAN, G.V., VAN NIEUWERBURGH, F., DEFORCE, D., CHANG, C., KAROL, K.G., HEDRICH, R., ULVSKOV, P., GLÖCKNER, G., DELWICHE, C.F., PETRÁŠEK, J., VAN DE PEER, Y., FRIML, J., BEILBY, M., DOLAN, L., KOHARA, Y., SUGANO, S., FUJIYAMA, A., DELAUX, P.M., QUINT, M., THEISSEN, G., HAGEMANN, M., HARHOLT, J., DUNAND, C., ZACHGO, S., LANGDALE, J., MAUMUS, F., VAN DER STRAETEN, D., GOULD, S.B., and RENSING, S.A., 2018. The Chara genome: secondary complexity and implications for plant terrestrialization. Cell, vol. 174, no. 2, pp. 448-464. http:// dx.doi.org/10.1016/j.cell.2018.06.033.

OUCHI, N., KIHARA, S., ARITA, Y., NISHIDA, M., MATSUYAMA, A., OKAMOTO, Y., ISHIGAMI, M., KURIYAMA, H., KISHIDA, K., NISHIZAWA, H., HOTTA, K., MURAGUCHI, M., OHMOTO, Y., YAMASHITA, S., FUNAHASHI, T. and MATSUZAWA, Y., 2001. Adipocyte-derived plasma protein, adiponectin, suppresses 
lipid accumulation and class A scavenger receptor expression in human monocyte-derived macrophages. Circulation, vol. 103, no. 8, pp. 1057-1063. http://dx.doi.org/10.1161/01.CIR.103.8.1057. PMid:11222466.

OUYANG, S., ZHU, W., HAMILTON, J., LIN, H., CAMPBELL, M., CHILDS, K., THIBAUD-NISSEN, F., MALEK, R.L., LEE, Y., ZHENG, L., ORVIS, J., HAAS, B., WORTMAN, J., and ROBIN BUELL, C. The TIGR rice genome annotation resource: improvements and new features. Nucleic Acids Research, 2007, vol. 35, suppl. 1, pp. D883-D887.

PARAG-SHARMA, K., LEYME, A., DIGIACOMO, V., MARIVIN, A., BROSELID, S. and GARCIA-MARCOS, M., 2016. Membrane recruitment of the non-receptor protein GIV/girdin ( $\mathrm{G} \alpha$ interacting, vesicle-associated protein/girdin) is sufficient for activating heterotrimeric $G$ protein signaling. Journal of Biological Chemistry, vol. 291, no. 53, pp. 27098-27111. http:// dx.doi.org/10.1074/jbc.M116.764431. PMid: 5207140.

PATIÑO-MEDINA, J.A., REYES-MARES, N.Y., VALLE-MALDONADO, M.I., JÁCOME-GALARZA, I.E., PÉREZ-ARQUES, C., NUÑEZ-ANITA, R.E., CAMPOS-GARCÍA, J., ANAYA-MARTÍNEZ, V., ORTIZ-ALVARADO, R., RAMÍREZ-DÍAZ, M.I., CHAN LEE, S., GARRE, V. and MEZACARMEN, V., 2019. Heterotrimeric G-alpha subunits Gpa11 and Gpa12 define a transduction pathway that control spore size and virulence in Mucor circinelloides. PLoS One, vol. 14, no. 12 , pp. e0226682. http://dx.doi.org/10.1371/journal.pone.0226682. PMid:31887194.

PENG, W.-X., ZHU, S.-L., ZHANG, B.-Y., SHI, Y.-M., FENG, X.X., LIU, F., HUANG, J.L. and ZHENG, S.G., 2017. Smoothened regulates migration of fibroblast-like synoviocytes in rheumatoid arthritis via activation of Rho GTPase signaling. Frontiers in Immunology, vol. 8, pp. 159. http://dx.doi.org/10.3389/fimmu.2017.00159. PMid:28261216.

PFEFFER, S.R., 2017. Rab GTPases: master regulators that establish the secretory and endocytic pathways. Molecular Biology of the Cell, vol. 28, no. 6, pp. 712-715. http://dx.doi.org/10.1091/mbc. e16-10-0737. PMid:28292916.

PINSON, S.R.M., TARPLEY, L., YAN, W., YEATER, K., LAHNER, B., YAKUBOVA, E., HUANG, X.-Y., ZHANG, M., GUERINOT, M.L. and SALT, D.E., 2015. Worldwide genetic diversity for mineral element concentrations in rice grain. Crop Science, vol. 55, no. 1, pp. 294-311. http://dx.doi.org/10.2135/cropsci2013.10.0656.

POCКЕТВООK, F.S., 2015. World food and agriculture. Rome: FAO Rome Italy.

PROELS, R.K. and ROITSCH, T., 2006. Cloning of a CACTA transposonlike insertion in intron I of tomato invertase Lin5 gene and identification of transposase-like sequences of Solanaceae species. Journal of Plant Physiology, vol. 163, no. 5, pp. 562-569. http://dx.doi.org/10.1016/j.jplph.2005.03.015. PMid:16473661.

QU, S., JEON, J.S., OUWERKERK, P.B., BELLIZZI, M., LEACH, J., RONALD, P. and WANG, G.L., 2009. Construction and application of efficient Ac-Ds transposon tagging vectors in rice. Journal of Integrative Plant Biology, vol. 51, no. 11, pp. 982-992. http:// dx.doi.org/10.1111/j.1744-7909.2009.00870.x. PMid:19903220.

REILLY, A., GIBRIEL, H.A., KARKI, S.J., TWAMLEY, T., FINNAN, J., KILDEA, S., and FEECHAN, A., 2021. Genome-wide identification of the oat MLO family and identification of a candidate AsMLO associated with powdery mildew susceptibility. BioRxiv, pp. 1-31. https://doi.org/10.1101/2021.03.22.435145.

REN, Z.-H., GAO, J.-P., LI, L.-G., CAI, X.-L., HUANG, W., CHAO, D.Y., ZHU, M.Z., WANG, Z.Y., LUAN, S. and LIN, H.X., 2005. A rice quantitative trait locus for salt tolerance encodes a sodium transporter. Nature Genetics, vol. 37, no. 10, pp. 1141-1146. http://dx.doi.org/10.1038/ng1643. PMid:16155566.
RIDLEY, A.J. and HALL, A., 1992. The small GTP-binding protein rho regulates the assembly of focal adhesions and actin stress fibers in response to growth factors. Cell, vol. 70, no. 3, pp. 389-399. http://dx.doi.org/10.1016/0092-8674(92)90163-7. PMid:1643657.

RIDLEY, A.J., PATERSON, H.F., JOHNSTON, C.L., DIEKMANN, D. and HALL, A., 1992. The small GTP-binding protein rac regulates growth factor-induced membrane ruffling. Cell, vol. 70, no. 3, pp. 401-410. http://dx.doi.org/10.1016/0092-8674(92)90164-8. PMid:1643658.

ROSS-MACDONALD, P., COELHO, P.S., ROEMER, T., AGARWAL, S., KUMAR, A., JANSEN, R., CHEUNG, K.H., SHEEHAN, A., SYMONIATIS, D., UMANSKY, L., HEIDTMAN, M., NELSON, F.K., IWASAKI, H., HAGER, K., GERSTEIN, M., MILLER, P., ROEDER, G.S. and SNYDER, M., 1999. Large-scale analysis of the yeast genome by transposon tagging and gene disruption. Nature, vol. 402, no. 6760, pp. 413-418. http://dx.doi.org/10.1038/46558. PMid: 10586881.

ROY, P., ROUT, A.K., MAHARANA, J., SAHOO, D.R., PANDA, S.P., PAL, A., NAYAK, K.K., BEHERA, B.K. and DAS, B.K., 2019. Molecular characterization, constitutive expression and GTP binding mechanism of Cirrhinus mrigala (Hamilton, 1822) Myxovirus resistance (Mx) protein. International Journal of Biological Macromolecules, vol. 136, pp. 1258-1272. http://dx.doi. org/10.1016/j.jbiomac.2019.06.161. PMid: 31242450.

SAALBACH, G. and THIELMANN, J., 1995. Isolation and characterization of five cDNA-clones encoding small GTP-binding proteins from field bean (Vicia faba). Journal of Plant Physiology, vol. 145, no. 5-6, pp. 665-673. http://dx.doi.org/10.1016/S01761617(11)81279-4.

SAIKA, H., NAKAZONO, M., IKEDA, A., YAMAGUCHI, J., MASAKI, S., KANEKATSU, M. and NEMOTO, K., 2005. A transposon-induced spontaneous mutation results in low $\beta$-amylase content in rice. Plant Science, vol. 169, no. 1, pp. 239-244. http://dx.doi. org/10.1016/j.plantsci.2005.03.022.

SANO, H. and YOUSSEFIAN, S., 1991. A novel ras-related rgp1 gene encoding a GTP-binding protein has reduced expression in 5-azacytidine-induced dwarf rice. Molecular and General Genetics MGG, vol. 228, no. 1, pp. 227-232. http://dx.doi.org/10.1007/ BF00282470. PMid:1715972.

SANO, H., SEO, S., ORUDGEV, E., YOUSSEFIAN, S. and ISHIZUKA, K., 1994. Expression of the gene for a small GTP binding protein in transgenic tobacco elevates endogenous cytokinin levels, abnormally induces salicylic acid in response to wounding, and increases resistance to tobacco mosaic virus infection. Proceedings of the National Academy of Sciences of the United States of America, vol. 91, no. 22, pp. 10556-10560. http://dx.doi. org/10.1073/pnas.91.22.10556. PMid:11607497.

SASAKI, T. and BURR, B., 2000. International Rice Genome Sequencing Project: the effort to completely sequence the rice genome. Current Opinion in Plant Biology, vol. 3, no. 2, pp. 138-141. http:// dx.doi.org/10.1016/S1369-5266(99)00047-3. PMid:10712951.

SATO, Y., SENTOKU, N., MIURA, Y., HIROCHIKA, H., KITANO, H. and MATSUOKA, M., 1999. Loss-of-function mutations in the rice homeobox gene OSH15 affect the architecture of internodes resulting in dwarf plants. The EMBO Journal, vol. 18, no. 4, pp. 992-1002. http://dx.doi.org/10.1093/emboj/18.4.992. PMid: 10022841.

SAZUKA, T., AICHI, I., KAWAI, T., MATSUO, N., KITANO, H. and MATSUOKA, M., 2005. The rice mutant dwarf bamboo shoot 1: a leaky mutant of the NACK-type kinesin-like gene can initiate organ primordia but not organ development. Plant $\mathcal{E}$ Cell Physiology, vol. 46, no. 12, pp. 1934-1943. http://dx.doi. org/10.1093/pcp/pci206. PMid:16183700. 
SCHMIDT, R.J., BURR, F.A. and BURR, B., 1987. Transposon tagging and molecular analysis of the maize regulatory locus opaque- 2 . Science, vol. 238, no. 4829, pp. 960-963. http://dx.doi. org/10.1126/science.2823388. PMid:2823388.

SCHNEIDER, A., KIRCH, T., GIGOLASHVILI, T., MOCK, H.-P., SONNEWALD, U., SIMON, R., FLÜGGE, U.I. and WERR, W., 2005. A transposon-based activation-tagging population in Arabidopsis thaliana (TAMARA) and its application in the identification of dominant developmental and metabolic mutations. FEBS Letters, vol. 579, no. 21, pp. 4622-4628. http://dx.doi.org/10.1016/j. febslet.2005.07.030. PMid:16087178.

SCHNELL, R.A. and LEFEBVRE, P.A., 1993. Isolation of the Chlamydomonas regulatory gene NIT2 by transposon tagging. Genetics, vol. 134, no. 3, pp. 737-747. http://dx.doi.org/10.1093/ genetics/134.3.737. PMid:8394263.

SCHWARTZ, A., CHAN, D.C., BROWN, L.G., ALAGAPPAN, R., PETTAY, D., DISTECHE, C., MCGILLIVRAY, B., DE LA CHAPELLE, A. and PAGE, D.C., 1998. Reconstructing hominid Y evolution: $\mathrm{X}$-homologous block, created by $\mathrm{X}-\mathrm{Y}$ transposition, was disrupted by Yp inversion through LINE-LINE recombination. Human Molecular Genetics, vol. 7, no. 1, pp. 1-11. http://dx.doi. org/10.1093/hmg/7.1.1. PMid:9384598.

SCHWARZ-SOMMER, Z., GIERL, A., CUYPERS, H., PETERSON, P.A. and SAEDLER, H., 1985. Plant transposable elements generate the DNA sequence diversity needed in evolution. The EMBO Journal, vol. 4, no. 3, pp. 591-597. http://dx.doi. org/10.1002/j.1460-2075.1985.tb03671.x. PMid:15926219.

SHAFIQUE, F., ALI, Q. and MALIK, A., 2020a. Effects of heavy metal toxicity on maze seedlings growth traits. Biological and Clinical Sciences Research Journal, pp. e027.

SHAFIQUE, F., ALI, Q. and MALIK, A., 2020b. Effects of water deficit on maize seedlings growth traits. Biological and Clinical Sciences Research Journal, pp. e28.

SHAN, Q., ZHANG, Y., CHEN, K., ZHANG, K. and GAO, C., 2015. Creation of fragrant rice by targeted knockout of the Os BADH 2 gene using TALEN technology. Plant Biotechnology Journal, vol. 13, no. 6, pp. 791-800. http://dx.doi.org/10.1111/pbi.12312. PMid:25599829.

SHI, J., GAO, H., WANG, H., LAFITTE, H.R., ARCHIBALD, R.L., YANG, M., HAKIMI, S.M., MO, H. and HABBEN, J.E., 2017. ARGOS 8 variants generated by CRISPR-Cas9 improve maize grain yield under field drought stress conditions. Plant Biotechnology Journal, vol. 15, no. 2, pp. 207-216. http://dx.doi.org/10.1111/ pbi.12603. PMid:27442592.

SIMON, M.I., STRATHMANN, M.P. and GAUTAM, N., 1991. Diversity of $G$ proteins in signal transduction. Science, vol. 252, no. 5007, pp. 802-808. http://dx.doi.org/10.1126/science.1902986. PMid:1902986.

SPEULMAN, E., VAN ASPEREN, R., VAN DER LAAK, J., STIEKEMA, W.J and PEREIRA, A., 2000. Target selected insertional mutagenesis on chromosome IV of Arabidopsis using the En-I transposon system. Journal of Biotechnology, vol. 78, no. 3, pp. 301-312. http:/ dx.doi.org/10.1016/S0168-1656(00)00203-0. PMid:10751691.

STEINER-LANGE, S., GREMSE, M., KUCKENBERG, M., NISSING, E., SCHÄCHTELE, D., SPENRATH, N., WOLFF, M., SAEDLER, H. and DEKKER, K., 2001. Efficient identification of Arabidopsis knock-out mutants using DNA-arrays of transposon flanking sequences. Plant Biology, vol. 3, no. 4, pp. 391-397. http://dx.doi. org/10.1055/s-2001-16468.

STEWART, G., MANN, A. and FENTEM, P., 1980. Amino acids and derivatives: a comprehensive treatise. USA: Elsevier. Enzymes of glutamate formation: glutamate dehydrogenase, glutamine synthetase, and glutamate synthase, pp. 271-327. http://dx.doi. org/10.1016/B978-0-12-675405-6.50013-9.

SUZUKI, Y., UEMURA, S., SAITO, Y., MUROFUSHI, N., SCHMITZ, G., THERES, K. and YAMAGUCHI, I., 2001. A novel transposon tagging element for obtaining gain-of-function mutants based on a self-stabilizing Ac derivative. Plant Molecular Biology, vol. 45, no. 2, pp. 123-131. http://dx.doi.org/10.1023/A:1006455130098. PMid:11289504.

TAHIR, T., ALI, Q., RASHID, M., and MALIK, A., 2020. The journey of CRISPR-Cas9 from bacterial defense mechanism to a gene editing tool in both animals and plants. Biological and Clinical Sciences Research Journal, pp. e017.

TAKAGI, K., ISHIKAWA, N., MAEKAWA, M., TSUGANE, K. and IIDA, S., 2007. Transposon display for active DNA transposons in rice. Genes E' Genetic Systems, vol. 82, no. 2, pp. 109-122. http:// dx.doi.org/10.1266/ggs.82.109. PMid:17507777.

TAKAI, Y., KAIBUCHI, K., KIKUCHI, A. and KAWATA, M., 1992. Small GTP-binding proteins. International Review of Cytology, vol. 133, pp. 187-230. http://dx.doi.org/10.1016/S0074-7696(08)618616. PMid: 1577587.

TAKANO, M., KANEGAE, H., SHINOMURA, T., MIYAO, A., HIROCHIKA, H. and FURUYA, M., 2001. Isolation and characterization of rice phytochrome A mutants. The Plant Cell, vol. 13, no. 3, pp. 521534. http://dx.doi.org/10.1105/tpc.13.3.521. PMid:11251094.

TAKASAKI, H., MARUYAMA, K., KIDOKORO, S., ITO, Y., FUJITA, Y., SHINOZAKI, K., YAMAGUCHI-SHINOZAKI, K. and NAKASHIMA, K., 2010. The abiotic stress-responsive NAC-type transcription factor OsNAC5 regulates stress-inducible genes and stress tolerance in rice. Molecular Genetics and Genomics, vol. 284, no. 3, pp. 173-183. http://dx.doi.org/10.1007/s00438-010-0557-0. PMid:20632034.

TERADA, R., URAWA, H., INAGAKI, Y., TSUGANE, K. and IIDA, S., 2002. Efficient gene targeting by homologous recombination in rice. Nature Biotechnology, vol. 20, no. 10, pp. 1030-1034. http://dx.doi.org/10.1038/nbt737. PMid:12219079.

TERRYN, N., VAN MONTAGU, M. and INZÉ, D., 1993. GTP-binding proteins in plants. Plant Molecular Biology, vol. 22, no. 1, pp. 143-152. http://dx.doi.org/10.1007/BF00039002. PMid:8499613.

TEZUKA, D., KAWAMATA, A., KATO, H., SABURI, W., MORI, H. and IMAI, R., 2019. The rice ethylene response factor OsERF83 positively regulates disease resistance to Magnaporthe oryzae. Plant Physiology and Biochemistry, vol. 135, pp. 263-271. http:// dx.doi.org/10.1016/j.plaphy.2018.12.017. PMid:30590260.

TOMITA, M. and TANISAKA, T., 2010. Long-culm mutations with dominant genes are induced by mPing transposon in rice. Hereditas, vol. 147, no. 6, pp. 256-263. http://dx.doi.org/10.1111/ j.1601-5223.2010.02162.x. PMid:21166795.

TSUGANE, K., MAEKAWA, M., TAKAGI, K., TAKAHARA, H., QIAN, Q., EUN, C.H. and IIDA, S., 2006. An active DNA transposon nDart causing leaf variegation and mutable dwarfism and its related elements in rice. The Plant Journal, vol. 45, no. 1, pp. 46-57. http:// dx.doi.org/10.1111/j.1365-313X.2005.02600.x. PMid:16367953.

TURCOTTE, K., SRINIVASAN, S. and BUREAU, T., 2001. Survey of transposable elements from rice genomic sequences. The Plant Journal, vol. 25, no. 2, pp. 169-179. http://dx.doi.org/10.1046/ j.1365-313x.2001.00945.x. PMid:11169193.

TYAGI, A.K. and MOHANTY, A., 2000. Rice transformation for crop improvement and functional genomics. Plant Science, vol. 158, no. 1-2, pp. 1-18. http://dx.doi.org/10.1016/S01689452(00)00325-3. PMid:10996240.

UEKI, N. and NISHII, I., 2008. Idaten is a new cold-inducible transposon of Volvox carteri that can be used for tagging developmentally important genes. Genetics, vol. 180, no. 3, 
pp. 1343-1353. http://dx.doi.org/10.1534/genetics.108.094672. PMid:18791222.

ULLAH, H., CHEN, J.-G., TEMPLE, B., BOYES, D.C., ALONSO, J.M., DAVIS, K.R., ECKER, J.R. and JONES, A.M., 2003. The $\beta$-subunit of the Arabidopsis $G$ protein negatively regulates auxin-induced cell division and affects multiple developmental processes. The Plant Cell, vol. 15, no. 2, pp. 393-409. http://dx.doi.org/10.1105/ tpc.006148. PMid:12566580.

VALLE-MALDONADO, M.I., PATIÑO-MEDINA, J.A., PÉREZ-ARQUES, C., REYES-MARES, N.Y., JÁCOME-GALARZA, I.E., ORTÍZ-ALVARADO, R., VELLANKI, S., RAMÍREZ-DÍAZ, M.I., LEE, S.C., GARRE, V. and MEZA-CARMEN, V., 2020. The heterotrimeric G-protein beta subunit $\mathrm{Gpb} 1$ controls hyphal growth under low oxygen conditions through the protein kinase A pathway and is essential for virulence in the fungus Mucor circinelloides. Cellular Microbiology, vol. 22, no. 10, pp. e13236. http://dx.doi. org/10.1111/cmi.13236. PMid:32562333.

VAN ACKER, T., TAVERNIER, J. and PEELMAN, F., 2019. The small GTPase Arf6: an overview of its mechanisms of action and of its role in host-pathogen interactions and innate immunity. International Journal of Molecular Sciences, vol. 20, no. 9, pp. 2209. http://dx.doi.org/10.3390/ijms20092209. PMid:31060328.

VAN ENCKEVORT, L.J., DROC, G., PIFFANELLI, P., GRECO, R., GAGNEUR, C., WEBER, C., GONZÁLEZ, V.M., CABOT, P., FORNARA, F., BERRI, S., MIRO, B., LAN, P., RAFEL, M., CAPELL, T., PUIGDOMÈNECH, P., OUWERKERK, P.B., MEIJER, A.H., PE', E., COLOMBO, L., CHRISTOU, P., GUIDERDONI, E. and PEREIRA, A., 2005. EU-OSTID: a collection of transposon insertional mutants for functional genomics in rice. Plant Molecular Biology, vol. 59, no. 1, pp. 99-110. http:// dx.doi.org/10.1007/s11103-005-8532-6. PMid:16217605.

VAN HOUWELINGEN, A., SOUER, E., MOL, J. and KOES, R., 1999. Epigenetic interactions among three dTph1 transposons in two homologous chromosomes activate a new excision-repair mechanism in Petunia. The Plant Cell, vol. 11, no. 7, pp. 13191336. PMid: 10402432.

VERMA, D.P.S., CHEON 3RD, C. and HONG, Z., 1994. Small GTPbinding proteins and membrane biogenesis in plants. Plant Physiology, vol. 106, no. 1, pp. 1-6. http://dx.doi.org/10.1104/ pp.106.1.1. PMid:12232299.

VERNOUD, V., HORTON, A.C., YANG, Z. and NIELSEN, E., 2003. Analysis of the small GTPase gene superfamily of Arabidopsis. Plant Physiology, vol. 131, no. 3, pp. 1191-1208. http://dx.doi. org/10.1104/pp.013052. PMid:12644670.

VERSTRAETEN, N., FAUVART, M., VERSÉES, W. and MICHIELS, J., 2011. The universally conserved prokaryotic GTPases. Microbiology and Molecular Biology Reviews, vol. 75, no. 3, pp. 507-542. http://dx.doi.org/10.1128/MMBR.00009-11. PMid:21885683.

VILLALBA, F., LEBRUN, M.-H., HUA-VAN, A., DABOUSSI, M.-J. and GROSJEAN-COURNOYER, M.C., 2001. Transposon impala, a novel tool for gene tagging in the rice blast fungus Magnaporthe grisea. Molecular Plant-Microbe Interactions, vol. 14, no. 3, pp. 308-315. http://dx.doi.org/10.1094/MPMI.2001.14.3.308. PMid:11277428.

WALBOT, V., 1992. Strategies for mutagenesis and gene cloning using transposon tagging and T-DNA insertional mutagenesis. Annual Review of Plant Biology, vol. 43, no. 1, pp. 49-78. http:// dx.doi.org/10.1146/annurev.pp.43.060192.000405.

WALBOT, V., 2000. Saturation mutagenesis using maize transposons. Current Opinion in Plant Biology, vol. 3, no. 2, pp. 103-107. http:// dx.doi.org/10.1016/S1369-5266(99)00051-5. PMid:10712955.

WANG, E., WANG, J., ZHU, X., HAO, W., WANG, L., LI, Q., ZHANG, L., HE, W., LU, B., LIN, H., MA, H., ZHANG, G. and HE, Z., 2008. Control of rice grain-filling and yield by a gene with a potential signature of domestication. Nature Genetics, vol. 40, no. 11, pp. 1370-1374. http://dx.doi.org/10.1038/ng.220. PMid:18820698.

WANG, S., XIE, K.,XU, G., ZHOU, H., GUO, Q., WU, J., LIAO, Z., LIU, N., WANG, Y., and LIU, Y., 2017. Plant G proteins interact with ER luminal protein receptors to regulate ER retrieval. Journal of Integrative Plant Biology, vol. 60, no. 7, pp. 541-561. https:// doi.org/10.1111/jipb.12648.

WANG, S., LI, S., LIU, Q., WU, K., ZHANG, J., WANG, S., WANG, Y., CHEN, X., ZHANG, Y., GAO, C., WANG, F., HUANG, H. and FU, X., 2015. The OsSPL16-GW7 regulatory module determines grain shape and simultaneously improves rice yield and grain quality. Nature Genetics, vol. 47, no. 8, pp. 949-954. http://dx.doi. org/10.1038/ng.3352. PMid:26147620.

WANG, Y.-M., DONG, Z.-Y., ZHANG, Z.-J., LIN, X.-Y., SHEN, Y., ZHOU, D. and LIU, B., 2005. Extensive de novo genomic variation in rice induced by introgression from wild rice (Zizania latifolia Griseb.). Genetics, vol. 170, no. 4, pp. 1945-1956. http://dx.doi. org/10.1534/genetics.105.040964. PMid:15937131.

WEI, X., JIAO, G., LIN, H., SHENG, Z., SHAO, G., XIE, L., TANG, S., XU, Q. and HU, P., 2017. GRAIN INCOMPLETE FILLING 2 regulates grain filling and starch synthesis during rice caryopsis development. Journal of Integrative Plant Biology, vol. 59, no. 2, pp. 134-153. http://dx.doi.org/10.1111/jipb.12510. PMid:27957808.

WESSLER, S.R., 1989. The splicing of maize transposable elements from pre-mRNA: a minireview. Gene, vol. 82, no. 1, pp. 127-133. http://dx.doi.org/10.1016/0378-1119(89)90037-1. PMid:2555263.

WILLIAMS, J.H. and FRIEDMAN, W.E., 2002. Identification of diploid endosperm in an early angiosperm lineage. Nature, vol. 415, no. 6871, pp. 522-526. http://dx.doi.org/10.1038/415522a. PMid: 11823859.

WILSON, K., LONG, D., SWINBURNE, J. and COUPLAND, G., 1996. A dissociation insertion causes a semidominant mutation that increases expression of TINY, an Arabidopsis gene related to APETALA2. The Plant Cell, vol. 8, no. 4, pp. 659-671. PMid:8624440.

WU, J., CHEN, L., CHEN, M., ZHOU, W., DONG, Q., JIANG, H. and CHENG, B., 2019. The DOF-domain transcription factor ZmDOF36 positively regulates starch synthesis in transgenic maize. Frontiers of Plant Science, vol. 10, pp. 465. http://dx.doi. org/10.3389/fpls.2019.00465. PMid:31031791.

WU, J., WU, C., LEI, C., BARAOIDAN, M., BORDEOS, A., MADAMBA, M.R., RAMOS-PAMPLONA, M., MAULEON, R., PORTUGAL, A., ULAT, V.J., BRUSKIEWICH, R., WANG, G., LEACH, J., KHUSH, G. and LEUNG, H., 2005. Chemical- and irradiation induced mutants of indica rice IR64 for forward and reverse genetics. Plant Molecular Biology, vol. 59, no. 1, pp. 85-97. http://dx.doi. org/10.1007/s11103-004-5112-0. PMid:16217604.

XIANG, Y., TANG, N., DU, H., YE, H. and XIONG, L., 2008. Characterization of OsbZIP23 as a key player of the basic leucine zipper transcription factor family for conferring abscisic acid sensitivity and salinity and drought tolerance in rice. Plant Physiology, vol. 148, no. 4, pp. 1938-1952. http://dx.doi. org/10.1104/pp.108.128199. PMid:18931143.

XIE, B., ZHENG, X., ZHOU, Z., GU, J., ZHU, B., CHEN, X., SHI, Y., WANG, Y., ZHAO, Z., LIU, C., YAO, Z. and ZHU, J., 2010. Effects of nitrogen fertilizer on $\mathrm{CH} 4$ emission from rice fields: multi-site field observations. Plant and Soil, vol. 326, no. 1, pp. 393-401. http://dx.doi.org/10.1007/s11104-009-0020-3.

XING, G., LI, J., LI, W., LAM, S.M., YUAN, H., SHUI, G. and YANG, J., 2021. AP2/ERF and R2R3-MYB family transcription factors: potential associations between temperature stress and lipid metabolism in Auxenochlorella protothecoides. Biotechnology 
for Biofuels, vol. 14, no. 1, pp. 1-16. http://dx.doi.org/10.1186/ s13068-021-01881-6. PMid:33451355.

XING, T., HIGGINS, V.J. and BLUMWALD, E., 1997. Identification of G proteins mediating fungal elicitor-induced dephosphorylation of host plasma membrane H+-ATPase. Journal of Experimental Botany, vol. 48, no. 2, pp. 229-237. http://dx.doi.org/10.1093/ $\mathrm{jxb} / 48.2 .229$.

XU, J., YANG, L., WANG, Z., DONG, G., HUANG, J. and WANG, Y., 2006. Toxicity of copper on rice growth and accumulation of copper in rice grain in copper contaminated soil. Chemosphere, vol. 62, no. 4, pp. 602-607. http://dx.doi.org/10.1016/j. chemosphere.2005.05.050. PMid:16081136.

YAMAGUCHI, T., HAYASHI, T., NAKAYAMA, K. and KOIKE, S., 2006. Expression analysis of genes for callose synthases and Rho-type small GTP-binding proteins that are related to callose synthesis in rice anther. Bioscience, Biotechnology, and Biochemistry, vol. 70, no. 3, pp. 639-645. http://dx.doi.org/10.1271/bbb.70.639. PMid:16556979.

YING, J.-Z., MA, M., BAI, C., HUANG, X.-H., LIU, J.L., FAN, Y.Y. and SONG, X.J., 2018. TGW3, a major QTL that negatively modulates grain length and weight in rice. Molecular Plant, vol. 11, no. 5 , pp. 750-753. http://dx.doi.org/10.1016/j.molp.2018.03.007. PMid:29567450.

YOUSEF, F., SHAFIQUE, F., ALI, Q. and MALIK, A., 2020. Effects of salt stress on the growth traits of chickpea (Cicer arietinum L.) and pea (Pisum sativum L.) seedlings. Biological and Clinical Sciences Research Journal, e029. https://doi.org/10.47264/bcsrj0101029.

YOUSSEFIAN, S., NAKAMURA, M. and SANO, H., 1993a. Molecular characterization of rgp2, a gene encoding a small GTP-binding protein from rice. Molecular and General Genetics $M G G$, vol. 237, no. 1, pp. 187-192. http://dx.doi.org/10.1007/BF00282800. PMid:8455556.

YOUSSEFIAN, S., NAKAMURA, M. and SANO, H., 1993b. Tobacco plants transformed with the O-acetylserine (thiol) lyase gene of wheat are resistant to toxic levels of hydrogen sulphide gas. The Plant Journal, vol. 4, no. 5, pp. 759-769. http://dx.doi. org/10.1046/j.1365-313X.1993.04050759.x. PMid:8275097.

YU, J., HU, S., WANG, J., WONG, G.K.-S., LI, S., LIU, B., DENG, Y., DAI, L., ZHOU, Y., ZHANG, X., CAO, M., LIU, J., SUN, J., TANG, J., CHEN, Y., HUANG, X., LIN, W., YE, C., TONG, W., CONG, L., GENG, J., HAN, Y., LI, L., LI, W., HU, G., HUANG, X., LI, W., LI, J., LIU, Z., LI, L., LIU, J., QI, Q., LIU, J., LI, L., LI, T., WANG, X., LU, H., WU, T., ZHU, M., NI, P., HAN, H., DONG, W., REN, X., FENG, X., CUI, P., LI, X., WANG, H., XU, X., ZHAI, W., XU, Z., ZHANG, J., HE, S., ZHANG, J., XU, J., ZHANG, K., ZHENG, X., DONG, J., ZENG, W., TAO, L., YE, J., TAN, J., REN, X., CHEN, X., HE, J., LIU, D., TIAN, W., TIAN, C., XIA, H., BAO, Q., LI, G., GAO, H., CAO, T., WANG, J., ZHAO, W., LI, P., CHEN, W., WANG, X., ZHANG, Y., HU, J., WANG, J., LIU, S., YANG, J., ZHANG, G., XIONG, Y., LI, Z., MAO, L., ZHOU, C., ZHU,
Z., CHEN, R., HAO, B., ZHENG, W., CHEN, S., GUO, W., LI, G., LIU, S., TAO, M., WANG, J., ZHU, L., YUAN, L. and YANG, H., 2002. A draft sequence of the rice genome (Oryza sativa L. ssp. indica). Science, vol. 296, no. 5565, pp. 79-92. http://dx.doi.org/10.1126/ science.1068037. PMid:11935017.

YUAN-YUAN, L. and ZHANG, J.-P., 2006. Gene trapping techniques and current progress. Acta Genetica Sinica, vol. 33, no. 3, pp. 189-198. http://dx.doi.org/10.1016/S0379-4172(06)60039-5. PMid:16553206.

YUEN, R.K., THIRUVAHINDRAPURAM, B., MERICO, D., WALKER, S., TAMMIMIES, K., HOANG, N., CHRYSLER, C., NALPATHAMKALAM, T., PELLECCHIA, G., LIU, Y., GAZZELLONE, M.J., D’ABATE, L., DENEAULT, E., HOWE, J.L., LIU, R.S., THOMPSON, A., ZARREI, M., UDDIN, M., MARSHALL, C.R., RING, R.H., ZWAIGENBAUM, L., RAY, P.N., WEKSBERG, R., CARTER, M.T., FERNANDEZ, B.A., ROBERTS, W., SZATMARI, P. and SCHERER, S.W., 2015. Wholegenome sequencing of quartet families with autism spectrum disorder. Nature Medicine, vol. 21, no. 2, pp. 185-191. http:// dx.doi.org/10.1038/nm.3792. PMid:25621899.

ZBELL, B., HOHENADEL, H., SCHWENDEMANN, I. and WALTER-BACK, C. Is a GTP-binding protein involved in the auxin-mediated phosphoinositide response on plant cell membranes? In T.M. KONIJN, M.D. HOUSLAY and P.J.M. VAN HAASTERT, eds. Activation and desensitization of transducing pathways. USA: Springer, 1990, pp. 255-266. http://dx.doi.org/10.1007/978-3-642-83618-3_16.

ZERIAL, M. and MCBRIDE, H., 2001. Rab proteins as membrane organizers. Nature Reviews. Molecular Cell Biology, vol. 2, no. 2, pp. 107-117. http://dx.doi.org/10.1038/35052055. PMid:11252952.

ZHANG, Q., LI, J., XUE, Y., HAN, B. and DENG, X.W., 2008. Rice 2020: a call for an international coordinated effort in rice functional genomics. Molecular Plant, vol. 1, no. 5, pp. 715-719. http:// dx.doi.org/10.1093/mp/ssn043. PMid:19825575.

ZHANG, S.-W., LI, C.-H., CAO, J., ZHANG, Y.-C., ZHANG, S.Q., XIA, Y.F., SUN, D.Y. and SUN, Y., 2009. Altered architecture and enhanced drought tolerance in rice via the down-regulation of indole3-acetic acid by TLD1/OsGH3. 13 activation. Plant Physiology, vol. 151, no. 4, pp. 1889-1901. http://dx.doi.org/10.1104/ pp.109.146803. PMid:19776160.

ZHOU, Y., CAI, H., XIAO, J., LI, X., ZHANG, Q. and LIAN, X., 2009. Over-expression of aspartate aminotransferase genes in rice resulted in altered nitrogen metabolism and increased amino acid content in seeds. Theoretical and Applied Genetics, vol. 118, no. 7, pp. 1381-1390. http://dx.doi.org/10.1007/s00122-0090988-3. PMid:19259642.

ZHU, J.J., QIN, Y., ZHAO, M., VAN AELST, L. and MALINOW, R., 2002. Ras and Rap control AMPA receptor trafficking during synaptic plasticity. Cell, vol. 110, no. 4, pp. 443-455. http:// dx.doi.org/10.1016/S0092-8674(02)00897-8. PMid:12202034. 